University of South Florida

DIGITAL COMMONS

@ UNIVERSITY OF SOUTH FLORIDA
Digital Commons @ University of

South Florida

\title{
Asteroids, Ophiuroids, and Echinoids of the English Antarctic Expedition of 1907-1909: A translation of Astéries, Ophiures, et Échinides de l'Expédition Antarctique Anglaise de 1907-1909. British Antarctic Expedition 1907-1909, Reports on the Scientific Investigations 2 (Biology), 4: 25-66, London: W. Heinemann
}

René Koehler

John Lawrence

University of South Florida, lawr@usf.edu

Follow this and additional works at: https://digitalcommons.usf.edu/bin_books

\section{Recommended Citation}

Koehler, R. (2021). Asteroids, Ophiuroids, and Echinoids of the English Antarctic Expedition of 1907-1909: A translation of Astéries, Ophiures, et Échinides de l'Expédition Antarctique Anglaise de 1907-1909. British Antarctic Expedition 1907-1909, Reports on the Scientific Investigations 2 (Biology), 4: 25-66, London: W. Heinemann (J. M. Lawrence, Trans.). Herizos Press, Tampa.

This Book is brought to you for free and open access by the Integrative Biology at Digital Commons @ University of South Florida. It has been accepted for inclusion in Integrative Biology Books by an authorized administrator of Digital Commons @ University of South Florida. For more information, please contact digitalcommons@usf.edu. 


\section{BRITISH ANTARCTIC EXPEDITION 190\%-9}

UNDER THE COMMAND OF SIR E. H. SHACKLETON, C.V.O.

REPORTS ON THE SCIENTIFIC INYESTIGATIONS

IOL. II

\section{BIOIUGY}

EDTTOR - JAMES MURRAY

PART IV

ASTÉRIEs, OPHIUREs, ET ÉCHINIDES

BY R. KOEHLER

Lioss)

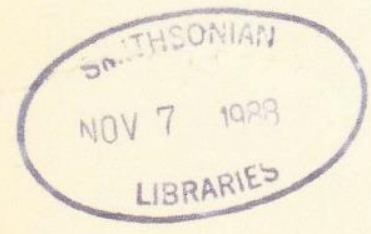

(HITH FUE PLATES)
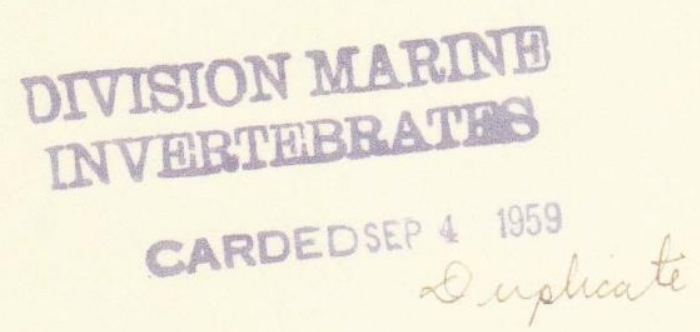

LONDON

PUBLISHED FOR THE EXPEDITION BY WILIAAM HEINEMANN

31. BEDFORD STREET, W.C.

1911

ISSUED SEPARATELY, JUNE, 1911

Phice 5s. Set 
Asteroids, Ophiuroids, and Echinoids of the English Antarctic Expedition of 1907-1909. A translation of Kohler, R. (1911). Astéries, Ophiures, et Échinides de l'Expédition Antarctique Anglaise de 1907-1909. British Antarctic Expedition 1907-1909, Reports on the Scientific Investigations 2 (Biology). 4: 25-66., London: W. Heinemann. (J. M. Lawrence, Trans.)

(C) J. M. Lawrence. 2021. Herizos Press, Tampa.

Translator's notes:

I have not attempted to correct apparent errors in the text.

As in the title, Kohler uses "English Antarctic Expedition" instead of "British Antarctic Expedition" throughout the text.

The cover of the publication gives Kœhler's name as “Koehler”.

I thank Janessa Fletcher for preparation of the plates. 


\title{
PART IV
}

\section{ECHINODERMA}

\author{
ASTEROIDS, OPHIUROIDS AND ECHINOIDS \\ OF THE ENGLISH ANTARCTIC EXPEDITION OF 1907-1909 \\ BY R. KEHLER \\ Professor at the University of Lyon
}

(With Plates IV to VIII)

James Murray has kindly asked me to study the asteroids, ophiuroids and echinoids collected by the Nimrod, Commander E. Shackleton, to South Victoria Land in 1907-1909. I would like to thank him here for the confidence that he has placed in me.

All the echinoderms collected came from Cape Royd, which is the westernmost point of Ross Island in South Victoria Land, at $77^{\circ} 32^{\prime}$ lat. S and $166^{\circ} 12^{\prime}$ long. E. Victoria Land and its neighboring regions have already been explored from the zoological point of view. The Southern Cross and the Discovery have brought back collections that have been studied and several species of echinoderms there are known. So, we could suppose that the echinoderms would not have a very great interest and only contain representatives of a fauna already known. These predictions have not been met, happily. The collection sent to me, although not very large, is on the contrary very interesting, not only because of the new species but also because of the information it gives on the geographical distribution of some species.

The zoological explorations of the Antarctic have mainly been done in two different and nearly opposite directions. Some, which departed from the Strait of Magellan, have had they object of studying the regions located to the south of the southern tip of South America: the Orcades and the South Shetlands, Graham Land, Danco Coast, etc., i.e., between $50^{\circ}$ and $70^{\circ}$ long. W. The others, which departed from Australia or New Zealand, which have introduced us to regions such as South Victoria Land, located toward $170^{\circ}$ long W. There is between these two extreme points a territory scarcely known although the Belgica went up to $100^{\circ}$ long. W and the Français up to $126^{\circ}$ long. W. 
The echinoderms collected by the Nimrod include six asteroids, four ophiuroids and three echinoids, thirteen species in all, of which eight are new and three new genera. Here is the list.

\section{ASTEROIDS}

Odontaster validus Kœhler

Cryaster antarcticus Kœhler

Porania antarctica Smith

Ophioglypha resistens, n. sp.

Ophioglypha flexibilis, n. sp.
Coscinasterias brucei Kœhler

Coscinasterias victoria, $\mathrm{n}$. $\mathrm{sp}$.

Notasterias armata, n. gen., n. sp

OPHIUROIDS

Amphiura algida, n. sp.

Ophiodiplax disjuncta, n. gen., n. sp.

\section{ECHINOIDS}

Sterechinus neumayeri Meissner

Abatus shackletoni, n. sp.
Pseudabatus nimrodi, n. gen., n. sp.

It is rather interesting to note that, except for a single and unique exception, none of the species above were collected by the Discovery from South Victoria Land. The echinoderms encountered by this vessel had a composition completely different according to the report of J. Bell (08), ${ }^{1}$ It seems useful to me to recall here the species reported by this naturalist:

Asterias brandti Bell

Asterias longstafi Bell

Heureaster hodgsoni Bell

Pentagonaster incertus Bell

Leptoptychaster kerguelensis_Smith

Cycethra verrucose Philippi

Henricia ornate Perrier

Solaster octordiatus Ludwig

Ophioglypha kohleri Bell

Ophiozona inermis Bell

Ophiosteira antarctica Bell
Ophionotus victoria Bell

Ophiacantha_imago Lyman

Ophiacantha vivipara Ljungmann

Ophiacantha cosmica Lyman

Ophioconis antarctica Lyman

Amphiura belgica Kœhler Bell

Astrotoma agassizii Lyman

Young ophiuroid

Austrocidaris canaliculata Agassiz

Sterechinus margaritaceus Lamarck

Abatus cavernosus Philippi

The only species in this list that I have not found among the echinoderms of the Nimrod is the "young ophiuroid" that J. Bell is content to figure without describing it. We shall see later that this form that the wise English naturalist considered as young has all the characteristics of an adult.

The English Antarctic Expedition brought back five species that were already known. They still have not been reported from Victoria Land. Two other species are more or less common in the Antarctic region. These are Porania antarctica and Sterechinus neumayeri. The first species is very widespread in the Antarctic and subantarctic regions. The Nimrod has collected it at a very high latitude ( $77^{\circ} 32^{\prime}$ S.), although its most southern station noted by the Belgica was located at

\footnotetext{
${ }^{1}$ The numbers in bold refer to the works cited that can be found at the end of this memoir.
} 
$71^{\circ} 18^{\prime}$. Sterechinus neumyeri also has a rather vast geographical distribution. We know it at the Strait of Magellan, South Georgia, South Orcades, Graham Land, etc. Mortensen tells us (10, p. 68 ) it has been found at several stations by the Swedish Antarctic Expedition. He believes it must be circumpolar. Its distribution is obviously because it has a pelagic larva. There is thus nothing surprising that it has been collected at Cape Royds.

The three other species have until now a habitat much more restricted. Coscinasterias brucei is known only at South Orcades where the Scotia found it. Cryaster antarcticus was found by the Français near $65^{\circ}$ lat. S.

Finally, Odontaster validus has been found by the Français near Graham Land and the Danco Coast, and by the Scotia at South Orcades. These locations, between $50^{\circ}$ and $70^{\circ}$ long. W., are, we see, very far from Cape Royds.

I have said above that all the echinoderms come from Cape Royds. According to the information that has been sent me, the specimens collected at a depth of 10 to 20 fathoms came from a small bay with a very sticky black mud. Those that were collected at 40 to 80 fathoms were dredged on a light-colored bottom with a very rich fauna.

\author{
ASTEROIDS \\ ODONTASTER VALIDUS, Kœhler \\ Odontaster validus, Kœhler (06), p. 6
}

Cape Royds, June 1908. Depth, 7-20 fathoms. Several specimens.

One of the specimens is very large: $\mathrm{R}=68 \mathrm{~mm}$. It is very robust. The thickness at the center of the disk exceeds $20 \mathrm{~mm}$. Five other individuals are small, $\mathrm{R}$ varies between 38 and $25 \mathrm{~mm}$. Finally, other much smaller individuals in which $\mathrm{R}$ varies between 15 and $8 \mathrm{~mm}$ are found in the collection.

PORANIA ANTARCTICA, Smith

For the bibliography, see:

Perrier (91), p. 107 and 163.

Leitpold (95)m p. 577,

Ludwig (05), p. 51.

Cape Royds. 20 August 1908. Depth, 60-80 fathoms. Two specimens.

The specimens are very young. Both have the same size: $\mathrm{R}=20 \mathrm{~mm}$ and $\mathrm{r}=8 \mathrm{~mm}$. But in one of them, the disk is smaller while the arms are slenderer and longer than in the other. Authors agree to consider, as part of the same species, $P$. antarctica Smith, magellanica Studer, glaber Sladen, and spinulata Sladen. Porania antarctica, in fact, varies greatly in their characters. Perrier has even remarked that some forms are near to $P$. pulvillus of northern seas.

The two individuals that I have before my eyes have a new example of this variation. The one with shorter and wider arms and a comparatively large disk, has about twelve conical and very apparent tubercles on the disk. On the arms, these tubercles are much smaller but rather numerous and close together. The specimen thus corresponds by these characters to $P$. antarctica. In the 
other, whose arms are thin and elongated, there is not the least trace of tubercles or protrusions on the dorsal surface. It thus recalls the form described by Sladen under the name P. glaber.

Because of these variations that have been noted by different authors on the Porania from various regions of the Antarctic, it seems we can only establish a distinction between the forms of the Kerguelen Islands and those of the extreme southern end of South America.

$P$. antarctica seems to have a rather vast area of distribution in the Antarctic regions. The Belgica encountered it at $71^{\circ} 18^{\prime}$ lat. S. We see that it goes still further toward the pole because the English Expedition collected it at $77^{\circ} 32^{\prime}$ lat. S.

CRYASTER ANTARCTICUS Kœhler (Pl. IV, fig. 1 and 2)

Cryaster antarcticus, Kœhler (06), p. 24, Pl. 1, fig. 1 and Pl. II, fig. 10.

Backdoor Bay. 6 February 1907. Depth 6-13 fathoms. One specimen.

The specimen is in an excellent state of preservation. At first glance, it seems rather different from the type of $C$. antarcticus that I described after the individuals reported by the first Expedition of Dr. Charcot. While in the latter, the dorsal and ventral surfaces of the body have numerous small spines that are close together, the specimen of the English Antarctic Expedition appears completely without spines. In fact, these spines are nearly completely missing and we find, in general, only the integumentary sheath of the spines, they having disappeared. But I have happily encountered in the recent collections during the second Expedition of Dr. Charcot that have just be entrusted to me, some specimens of $C$. antarcticus in which the spines are much less developed than in the type and can remain completely hidden in the integument, so that this individual from Victoria Land appears like the last step of a series of which I have the principal stages. Thus, there is no reason at this point not to relate it to $C$. antarcticus.

The five arms are subequal but, as they more or less contorted and raised toward the dorsal surface, it is difficult to measure their exact length. $\mathrm{R}$ of the largest arms varies from 120 to 130 $\mathrm{mm} ; \mathrm{r}=49 \mathrm{~mm}$.

The disk is very thick. Its maximum height attains $47 \mathrm{~mm}$. It has the form of a low cone with a very blunt top that is widely continuous with the arms.

We note, along each interradius, a rather wide depression that is accentuated as it approaches the edge of the disk. The base of the arms is thus clearly delimited. This base is very wide. It measures $48 \mathrm{~mm}$ on the widest arm and 38 on the narrowest. They narrow very rapidly on the first half and then, in a slower manner, narrow progressively up to the end that is narrow and obtuse.

Despite the absence of calcareous deposits in the integument of the dorsal surface, it is very resistant and non-deformable. The integument that covers it is thick and strong. The entire animal is robust. The outermost layer of this integument, whose thickness attains at least a millimeter, is constituted of very irregular and unequal protuberances that are very close to each other and separated by very fine grooves. These protuberances have a surface sometimes smooth, sometimes pleated. As a whole, they recall the pustules that we see on the surface of some Anasterias, but they are much smaller in this latter genus because the largest does not reach a centimeter in width.

The small spines that I reported in 1906 in the $C$. antarcticus coming from the first Charcot Expedition, emerged from similar protuberances. Their base remained sunken for a more or less long length. In the soft tissue they formed thus a collarette. Here the spine was completely missing and only the collarette of the spine remained. I have examined with the microscope a large number 
of these pustules without being able to discover there the least indication of spines or calcareous deposits. On some of them, we see raised a small central protuberance, conical, with an obtuse point, but this does not enclose the least trace of a spine. We cannot accept that the spines have been dissolved by reactive preservatives because I observe them on the ventral surface as I shall say later.

The appearance of the dorsal surface of this individual is completely identical to that I observe in some individuals coming from the second Expedition Charcot in which this surface has no apparent spine. But microscopic examination of the collarettes or pustules of these individuals show that each of them enclose a small internal spine.

Toward the center of the disk, the small pustules flatten progressive. They disappear over a space measuring approximately $15 \mathrm{~mm}$ in diameter that is filled with a smooth integument on which is seen however a fine polygonal network representing without doubt the impression of the vanished pustules. It seems that this region is subjected to pressures or abrasions that have compressed or removed the superficial parts of the integument. At the center of this region is a very small pore that perhaps corresponds to the anus.

Among the pustules are found very numerous elongate papulae whose length attains 2 to 3 $\mathrm{mm}$. Their very soft walls are thin, transparent and colorless. They contrast to the other parts of the integument whose color is pale brown.

The layer thus constituted by the coverings of aborted spines and the papulae attains a thickness of at least $1 \mathrm{~mm}$. Below it is a resistant connective tissue layer, white in color, formed of a very dense tissue having circular openings through which the papulae pass. The superficial layer of the integument has the feel of velvet to the hand.

The madreporite, very long and elongated in the interradial direction, measures $10 \mathrm{~mm}$ by 7.5. It is located nearer the center than the border. Its surface is largely granuolose and the grooves are not apparent.

In the ventral interradial areas, the grooves that separate the integumentary protuberances are arranged in a regular manner, parallel to each other in going from the ambulacral groove to the borders of the disk and the arms. The integumentary protuberances themselves thus align in transverse rows that continue onto the borders of the disk and the arms, and pass to the pustules of the dorsal surface. Some of them, especially in the area of the mouth, contain a small spine that we find either by a microscopic examination or in testing the expansion with a needle, but none of these spines protrude outside. On the sides of the arms, but in the terminal part only, I observe also some conical protuberances, each containing an internal spine.

The ambulacral grooves are narrow. The tubes are placed without order, very close together. The adambulacral spines are arranged in three rows as I have described. They are very short, thick and surrounded by a strong integumentary envelope.

COSCINASTERIAS BRUCEI Kœhler (Pl. V, fig. 5)

Stolaster brucei Kœhler (08), p, 41, P1. V, fig. 46 and 47.

Cape Royds, 27 July 1908. Depth 10-18 fathoms. Four specimens.

The four specimens are very young and they are all nearly the same size. R measures no more than $27 \mathrm{~mm}$. They still have not acquired their definitive form, but they possess all the principal characters of $C$. brucei and I do not believe I am mistaken in relating it to this species that I have 
described after specimens collected by the Scotia in the South Orcades at a depth of 10 fathoms. For the reasons I shall indicate later, it appears more correct to me to place this asteroid in the genus Coscinasterias than in the genus Stolasterias to which I had first placed it.

The four individuals have the same characters. I have represented in $\mathrm{Pl}$. V, fig. 5, the dorsal surface of two that I have dried to make their characters more apparent. The disk has an external circle of very short and obtuse spines each surrounded by a collarette of crossed pedicellariae, not numerous, and, at the center, a small spine or a group of two or three spines. In the intermediary space, we see only some sparse spines. The carinal line is marked by a row of spines that has, as in the type of the species, more or less accentuated sinuosities. Between this line and the row of dorsal marginals, we see only isolated spines, always surrounded by their collarettes. But most of the sides of the arms remain bare. The spines are cylindrical. They have a rounded end having very fine and pointed teeth. The spines of the dorsal and ventral rows are flat and a little larger than the preceding. Their end is often a little enlarged. They also have very fine spinules. The ventral marginal row is very near the adambulacral spines from which it is simply separated by a narrow interval without the least trace of spines. This character conforms well with what exists in $C$. brucei, while there is a ventral row of spines in $C$. victoria that I shall describe below.

To the four specimens that I just mentioned were added a dozen extremely young individuals in which $\mathrm{R}$ ranged between 12 and $4 \mathrm{~mm}$. They very probably also belong to C. brucei.

In first relating $C$. bruce $i$ to the genus Stolasterias, I had given the latter genus the rather large importance indicated by Sladen and not the restricted meaning that it had then been given by Perrier. The different divisions that had been established by the latter scholar in the old genus Stolasterias of Sladen are perhaps not very necessary. On the other hand, the same limits assigned by Perrier to the genus Stolasterias are not very precise. Thus, this naturalist established in 1896 (Stellérides des Campagnes de I' Hirondelle, p. 34) a distinction between the genus Stolasterias and a new genus Distolasterias that he created, and that was based on the fact that the first has isolated adambulacral spines while the second has two of them per plate. However, three pages further (p. 37), he describes, under the name Stolasterias neglecta, a new species that has two rows of adambulacral spines. I cannot understand why the author has not related it to his genus Distolasterias rather than to the genus Stolasterias that is characterized, among other things, by the single row of adambulacral spines.

On the other hand, W. K. Fisher has shown (06, p.1104) that the genus Stolasterias corresponds exactly to the genus Coscinasterias, established by Verrill for $C$. muricata (which is synonymous with . calamaria Gray). The term Coscinasterias, is thus prior to the term Stolasterias because it dates to 1869 and the American naturalists thinks that, logically, the first should be substituted for the second. The genus Coscinasterias, taken in this widest sense, contains the following principal forms: calamaria, tenuispina, gemmifera, volsellata, stichantha, eustyle, glacialis, etc.

Without stating in a formal manner the necessity of subdividing the genus Coscinasterias, W. $\mathrm{K}$. Fisher proposed substituting for the genera established by Perrier the following divisions:

Coscinasterias Verrill, 1869; type, calamaria.

Stolasterias Sladen, 1889 (= Polyasterias Perrier); type, tenuispina.

Marthasterias Jullien, 1878; type, glacialis.

Distolasterias Perrier, 1896; type, stichantha.

It is worthwhile to note, in regard to these four sub-genera, that the last has not been used by its creator in the same work where he established it, and that the next to the last was based on a poorly preserved specimen of no value. On the other hand, one of the principal characters on which 
we can rely to separate the genus Coscinasterias (as well as the genus Polyasterias of Perrier), is the multiplicity of arms. Under these conditions, it does appear in a very evident manner that it is necessary to subdivide the old genus Coscinasterias of Verrill. So, I have believed it necessary to preserve this term in giving it the broadest application under which it would become exactly synonymous with the genus Stolasterias of Sladen.

COSCINASTERIAS VICTORIÆ, nov. sp. (Pl. V, fig. 3 and 4)

Cape Royds. 20 August 1908. Depth, 50-80 fathoms. One specimen. Cape Royds. 30 August 1908. Depth, 25 fathoms. One specimen.

The specimen of 20 August is in very good condition, although it has been slightly altered by being in formaldehyde. The five arms are a little unequal. In the smallest, $\mathrm{R}=68 \mathrm{~mm}$; in the others, $R$ varies from 75 to $82 \mathrm{~mm} ; \mathrm{r}=15 \mathrm{~mm}$. The arms are very slightly narrowed at the base and their maximum width varies between 18 and $20 \mathrm{~mm}$. They narrow progressively up to the end that is thin and pointed. It is this individual that will serve me as type for the description of the species. It is represented in Pl. V, fig. 3 and 4.

The specimen collected 30 August is not very well preserved. It is a little macerated and its tissues are a little soft. The body is flat. It has been subjected to some compression. Measured on the largest arm, R exceeds $130 \mathrm{~mm}$. The arms attain $27 \mathrm{~mm}$ in width at the base. They taper progressively up to the end that is pointed. $\mathrm{r}=20 \mathrm{~mm}$.

The disk is of medium size. Its diameter, measured between two non-consecutive inter-brachial spaces varies around $30 \mathrm{~mm}$. The dorsal surface of the arms is convex, slightly keeled on the median line. The lateral surfaces, between the dorsal and ventral marginal plates, are narrow. The skeleton of the arms is quite resistant. The whole animal is quite rigid.

The dorsal surface of the disk and the arms has spines that are little developed. They emerge from a collarette resembling a pustule of Anasterias. The collarettes are close to each other. Between them are numerous protruding papulae so that the underlying skeleton is absolutely invisible. The collarettes, with the spines that they cover, are much less distinct than in C. brucei. The rows they form are less clear than in the latter species.

The central region of the disk, with a diameter of $14 \mathrm{~mm}$, is filled by a first circle of spines surrounded by their collarettes that are contiguous, unequal and indistinct. These spines scarcely protrude outside the collarette. Their end is blunt. Inside, we see a second of less apparent spines whose collarettes are still small and less distinct than the preceding. The rest of the circular space is filled by collarettes lacking spines except at the center where there is a spine a little stronger than the others. Between the collarettes are numerous papulae.

The carinal line of the arms has a row of spines that leaves the exterior circle reported above and scarcely exceeds the collarette surrounding their base. The collarettes are close to each other and their borders are not very apparent in general. They form an irregular, sinuous line and their contours are not very distinct. The row they form on each row is, as a whole, quite recognizable in general. These rows are not very apparent in the photograph. The dimensions of these collarettes decreases very slowly but they become very small in the last quarter of the arm and, consequently, are very numerous. The central spines remain distinct up to the end of the arms. I count more than sixty collarettes in this carinal row. They are, as we see it, small, more numerous, and dense than in $C$. bruce $i$ where their number does not pass forty-five in a specimen of the same size. We can see, in comparing the photographs that I give here (Pl. V, fig. 3) of C. victorice to the figure that I 
have published of $C$. brucei $(\mathbf{0 8}, \mathrm{Pl}$. V, fig. 46), that, in the latter, the collarettes keep the same dimensions on nearly all the length of the arms and that they are hardly closer together and smaller toward the end, while here it is quite different. The sinuosities are more accentuated in C. victoriae, but the line itself is, all together, less distinct than in $C$. brucei. The very wide space between the carinal row and the dorsal marginal row is filled by confluent collarettes whose contours are nearly always poorly indicated and that are a littler smaller and less developed than those of the carinal row. We recognize, in places, an arrangement of two or three longitudinal rows on each side. From the center of each collarette generally rises a very short and obtuse small spine. Finally, numerous papulae are seen between the collarettes.

In the large specimen, the contours of the collarettes are better marked. They are round or irregularly polygonal by reciprocal pressure. Those of the carinal line are not much larger than the others. They measure approximately $2.5 \mathrm{~mm}$ in width. They are arranged in a line much less sinuous than in the first individual, but more distinct in contrast. The central spine always remains not very projecting. The lateral collarettes form three or four fairly regular longitudinal rows. They form equally slightly oblique transverse rows more or less apparent, in each of which they are most often four. The form of these collarettes is irregularly polygonal. The width attains $2 \mathrm{~mm}$. They are rather separated from each other, as distinct and nearly as large as those of the carinal row. Their borders are much better marked than in the other specimen. Each of them has a short, blunt central spine. The papulae are always abundant. They are especially numerous toward to edges of the arms where they form small regular groups between successive collarettes.

The dorsal edge of the arms is occupied by a row of large, flat spines, with a truncated and slightly enlarged end, each rising from the center of a collarette. Their free region measures approximately $1.5 \mathrm{~mm}$ in height. The surface of these spines is canaliculated. These collarettes, rectangular in form, are a little larger than those of the dorsal surface of the arms. Toward the end of the arms, the spines are shorter and closer together. They become then very numerous as happens for the carinal row.

The spines of the ventral marginal row correspond to those of the dorsal marginal row, but they are thicker and stronger, all while keeping the same general form. The collarettes that surround the bade are identical to those of the dorsal row. Between these two rows of marginal spines, the lateral surfaces of the arms, very narrow, are filled with very dense papulae and even completely contiguous, forming a band whose width, at the base of the arms, does not exceed two millimeters.

The ventral surface of the arms has a row of spines that corresponds nearly exactly to that of the ventral marginal row, but they are a little less developed. They become smaller in the second half of the arms and, in the last quarter, they occur only at rather spaced intervals. This row is completely contiguous to the adambulacral spines and to those of the ventral marginal row in the specimen that serves at my type. In the larger, it is separated from the first by a narrow, but very apparent, space. Unfortunately, the ventral surface of the latter individual is in such bad condition that it is not proper to study.

The ambulacral grooves are very wide. The tubes form four irregular rows. The adambulacral spines are arranged in two rows. They are rather short, but strongly flattened in the transverse direction. Their end is truncated and round. The two rows are nearly identical. Five spines of the external row nearly correspond to two spines of the ventral marginal row.

All these spines, like those of the ventral and ventral marginal rows, are enveloped by a rather thick integument that completely covers them. 
Each of the teeth has, at their proximal point, two cylindrical spines, with a round end thinner than the adambulacrals. On their ventral surface, we see a stronger spine, with a truncated end and recalling more the adambulacral spines from which it differs however by its cylindrical form.

There are, as usual, rather numerous crossed pedicellariae in the tissue of the collarettes and straight pedicellariae from place to place on the walls of the ambulacral groove. Unfortunately, the calcareous tissue of these little organs has been attacked by the formaldehyde and we cannot recognize the structure.

Similarities and differences. - C. victorice is very near C. brucei. It is distinguished from it by its thinner and comparatively longer arms, by the number of carinal spines, much higher because these spines become very small and dense in the terminal part of the arms, by the more numerous spines on the dorsal surface of the arms where they even form several longitudinal fairly recognizable rows in the large specimen and finally by the presence of a distinct row of spines on the ventral surface between the external adambulacral spines and ventral marginal row. The spines of the two adambulacral rows as well as those of the ventral and ventral marginals rows are enveloped by an integument that completely covers them, an arrangement I have not observed in C. brucei.

\section{NOTASTERIAS, nov. gen.}

The skeleton of the arms has five regular rows of plates, one carinal, two dorsal marginals and two ventral marginals, as is the rule in the genus Coscinasterias and close genera. There is, in addition, a beginning of a ventral row. Each plate has a rather developed single spine but lacks collarettes with crossed pedicellariae. The spines of the carinal row have, at their base, each a pedicellaria with crossed valves but belonging to a particular type. Their dimensions are truly considerable because their length can reach and even exceed $2 \mathrm{~mm}$. These pedicellariae are also isolated at the base of the spine. They have the same characters as those I have described in Asterias pedicellaris collected by the Scotia (08, p. 49). Their structure differs from that of ordinary forcipulate pedicellariae. I propose to give them the name of macrocephalous. I shall return later to their characters. At the base of the spines of the dorsal and ventral marginal plate, we encounter one and sometimes two macrocephalous pedicellariae, but these pedicellariae are much smaller than those that accompany the carinal spines. Some of these marginal spines have in addition ordinary crossed pedicellariae, one or two at most, attached to the spine itself between its base and its middle. These forcipulate pedicellariae are always smaller than the nearby macrocephalous pedicellariae. They measure in fact approximately $0.4 \mathrm{~mm}$ in length, while the smallest macrocephalous pedicellariae attain nearly double.

In the only species known, which is of rather small size, there is no row of dorsal lateral plates. The papulae are isolated and very distinct, round and relatively rather large. They are spaced and form a first row between the carinals and the dorsal marginals, then a second, more regular, between the dorsal and ventral marginals. The adambulacral spines are arranged in four irregular rows. There are straight pedicellariae from place to place on the walls of the ambulacral groove. The ambulacral tubes form several irregular rows.

It seems useful to me to return to the characters of the macrocephalous pedicellariae that I have been able to study in the two specimens of the English Expedition as well as in the third specimen coming from the second Charcot Expedition, in a more complete manner than in Asterias 
pedicellaris where these large pedicellariae are rather rare. This study has convinced me that the differences between these pedicellariae and the forcipiform pedicellariae are rather marked so that we must consider the first as representing a separate form. This is why I have believed it necessary to give them a particular name.

Exteriorly, the macrocephalous are recognizable not only by their size, but also by their form that is conical, each of the two valves that form it taper to the end instead of forming a convex blade whose free border is wide, round and filled with a series of fine teeth. In addition, the end of each valve is curved and ends in a more or less developed hook that is crossed with its counterpart so that we can say that these pedicellariae are doubly crossed. In fact, their valves cross first at the level of their articulation with the basal piece, then, a second time, toward their end. We can see, in comparing the figures, that I have here of macrocephalous pedicellariae (Pl. V, fig. 6, 4, 11; $\mathrm{Pl}$. VI, fig. $4 \& 8$ ) to figures of forcipulate pedicellariae that have been published, either by Perrier, or more recently by Ludwig (08, Pl. VII, fig 66 to 68), how the two forms are different. In the large pedicellariae of Asterias pedicellaris, the terminal hook is not very developed, but it is always very strong and very developed in the young (see Kœhler, 08, Pl. VIII, fig. 75).

As I said in 1908, the valves of our pedicellariae are hollow. They have the form of a horn of which a part of the free border continues in a "tail" that articulates with the basal piece. In other words, the calcareous lamella that constitutes the valve, which coils up on itself for about half its length. The two borders of the coiled part back up against each other following a straight line that has conical and pointed teeth (Pl. V, fig. 8, 9 and 11; Pl. VI, fig. 5 and 6). These teeth are less numerous on the large pedicellariae than on the small. They are only on the proximal part of the sutural line in a way that all the region that precedes the hook lacks teeth. On the small pedicellariae, the teeth are more numerous and they occur on a greater length along the sutural line. In A. pedicellaris they can even go up to the area of the hook. They mesh with their counterpart of the opposite valve. The terminal hook is pointed, more or less elongated, sometimes straight, sometimes slightly curved.

The tail of the valve, rather long, is widened and concave. It ends in a round edge.

The calcareous blade that forms each valve is constituted of an areolated tissue, with small and very dense perforations. The same structure is seen the entire extent of the tail that is not constituted of a compact tissue. Only the hook that ends the valves is formed of a compact and transparent tissue.

We see thus that the valves of the macrocephalous pedicellariae, with their form of a cone or a horn, their terminal hook, their teeth arranged along the sutural line corresponds to one of the generators of the cone, and the tail formed of areolated calcareous tissue are very different from those of the crossed or forcipulate pedicellariae. The basal piece, on which the valves articulate, has, on the contrary, a composition little different from that we know in the latter (Pl. V, fig. 10, and Pl. VI, fig. 7). Its body represents a flat lamella, elongated in the genus Notasterias, shorter in Asterias pedicellaris, and that ends in a strongly convex edge. This one has an edge when we look at the pedicellaria in profile like that shown in Pl. V, fig. 6 and 7, while the lamella is flat when the pedicellaria is seen from the front (Pl. VI, fig. 4 and 8). The small, numerous perforations are arranged in linear rows, slightly divergent and extremely dense. The base of this lamella is thickened on its sides in a way to form two rounded edges that extend nearly perpendicularly to its plane. Each is continued forward and backwards by a kind of conical and rounded apophysis. These apophyses correspond respectively to the regular and irregular apophyses of Perrier. We note that one of the apophyses of one side is stronger than the other of the same side, but there is not, in development and direction, an inequality comparable to that which we know in the 
forcipulate pedicellariae. In the small macrocephalous pedicellariae, the apophyses are more pointed and elongated, and the lamella is, on the contrary, shorter. Also, when we look at the basal piece from the side, we see on the upper plane the two apophyses on one side and on the lower plane the two other apophyses, while the basal piece has only a little marked protuberance. It is the aspect shown in A. pedicllaris (08, Pl. VII, fig. 67). The lamella, less developed than in the genus Notasterias is completely invisible.

The adductor muscles of the valves are extremely developed. We see them by transparency on the pedicellariae mounted whole. They extend rather high in the interior of the valves (Pl. V, fig. 7, and Pl. VI, fig. 4).

The macrocephalous pedicellariae are always isolated. They are never embedded in collarettes at the base of the spines as we see in Asterias and close genera. Their valves are surrounded by a transparent connective tissue that is continued, at the base of the pedicellaria, by an extremely short and thin stalk, that aids in the attachment of the pedicellaria to the integument of the asteroid. There is no fibrous cord inserting on the basal piece as in the forcipiform pedicellariae.

The presence of a particular form of pedicellaria in an asteroid appears sufficient to me to justify the creation of a new genus, especially since the straight or crossed pedicellariae preserve a very uniform structure in all asteroids. I propose the apply the name Notoasterias to the asteroid discovered by the English Antarctic Expedition.

As I have had the occasion to recall above, I have encountered the same macrocephalous pedicellariae in an asteroid collected by the Scottish Antarctic Expedition at a depth of 1410 fathoms and that I described under the name Asterias pedicellaris But this latter could not be placed in the genus Notasterias. It differs from it, in fact, by the constitution of its skeleton, by the irregular distribution of the macrocephalous pedicellariae, by the absence of forcipulate pedicellariae and the adambulacral spines not forming a single row. I believe that it necessary to remove this species from the genus Asterias and I am disposed to make it the type of a new genus that we could call Autasterias. The distinctive characters of these two Antarctic genera can be summarized in the following way.

Notasterias. - The skeleton of the arms is formed by five longitudinal rows of rather large plates and united in a way to form a compact skeleton leaving only small openings for the passage of papulae that are isolated. Each plate has a spine lacking collarettes with forcipulate pedicellariae. The carinal spines have each at their base a single large macrocephalous pedicellaria. Similar pedicellariae, but smaller, can be encountered at the base of the dorsal and ventral marginal spines. These spines can, in addition, have some forcipulate pedicellariae. The adamabulacral spines are arranged in two rows.

A single species, Antarctic and littoral.

Auasterias. - The skeleton of the arms is formed of five longitudinal rows of small plates, each with a spine and connected by braces that leave between them very large meshes. In the calcareous network of the dorsal surface, but especially not at the base of each spine, are found scattered some large macrocephalous pedicellariae. There are no pedicellariae at the base of the spines of the carinal and dorsal marginal plate. But at the base of each ventral marginal plate, there is a group of some small macrocephalous pedicellariae. The foricuplate pedicellariae are completely missing. The adambulacral spines form only a single row.

A single species, Antarctic and abyssal. 
NotAsterias ARMATA, nov. sp. (Pl. V, fig. 6 to 11 ; Pl. VI, fig. 1 to 8)

Cape Royds Bay. 2 July 1908. Depth, 10-18 fathoms. Two specimens.

The arms are a little unequal. In the larger individual, $\mathrm{R}=25$ to $28 \mathrm{~mm}, \mathrm{r}=5.5 \mathrm{~mm}$. In the second, $\mathrm{R}=17$ to $20, \mathrm{r}=4 \mathrm{~mm}$.

The integument is fairly thick. It completely hides the contours of the underlying plates. In order to be able to study the latter, I have dried the smaller specimen in which the contours of the plates became very apparent. I show here the larger individual (Pl. VI, fig. 1 and 2).

The disk is small, the arms are very distinct, but they are not narrowed at the base. Their width is $6.5 \mathrm{~mm}$ on average. It hardly decreases until the last quarter. The end is thin.

The dorsal surface of the disk of the small individual has on its periphery, a circle of ten plates, five radials and five interradials. The arrangement seems to be the same in the large individual. The center is occupied by a larger plate that connects to those of the periphery by radiating ossicles. Each plate has a rather strong spine, measuring 2.5 to $3 \mathrm{~mm}$ in length, rather wide at the base and then becoming cylindrical. The obtuse end has rugosities or fine teeth. Like the spines of the arms, these are covered by a thin integument. At the base of each spine is a large macrocephalous pedicellaria identical to those that we find on the arms, but a little smaller in general than the latter, except those found at the base of the central spine. The madreporite is small, elongated in the interradial direction and located nearly equal distance from the center and the edge. Its grooves are little marked.

The arms have five longitudinal rows of plates: a carinal, two dorsal marginals and two ventral marginals. The carinal row is very protruding, so that the arms a very strongly carinated. The dorsal marginal row is also very conspicuous. The ventral marginal row is rather far from the preceding and separated from it by a vertical surface. A section of the arm thus approaches a nearly regular polygon, whose base is a little larger than the others. The carinal plates, strong and protruding, have a trifoliated form due to the presence of three round lobes, the proximal lobe covering the median region of the preceding and the lateral lobes connecting by small rows to the dorsal marginal plates. The first three or four plates of each row have each a spine, but the following do not always have it and sometimes we find it only half the time. There are about a dozen spines on each arm in the larger specimen and eight on average in the smaller. The plates that have a spine are stronger than the others. These spines have the same characters as those of the disk. They are only a little longer. Their length attains generally $3 \mathrm{~mm}$. They absolutely lack collarettes with pedicellariae, but, at the base of each of them, is found a large macrocephalous pedicellaria whose length can attain nearly $3 \mathrm{~mm}$. Because of its size, this pedicellaria sometimes throws off the spine, either from one side or the other. As the size of these pedicellariae varies, the row of carinal spines appears more or less irregular.

The dorsal marginal plates have the same form and the same arrangement as the carinals, but they are a little more projecting than the latter. Their internal lateral lobes are united to those of the corresponding marginal plates only at the end of the arms. But on the rest of the length of the arms, we note two or three small intercalary plates. Most of the dorsal marginals have a spine recalling those of the carinals, but a little smaller. The spines appear more frequent than on the latter plates. In principle, the dorsal marginal plates correspond to the carinals, but the correspondence is sometimes disrupted because of the presence or absence of spines on the plates considered. Some spines at the beginning of the arms have at their base, macrocephalous 
pedicellaria constituted like those of the carinal series, but a little smaller. These macrocephalous pedicellariae are not very numerous on the two specimens of the English Expedition. I shall have the opportunity to note later that in a specimen of Notasterias armata, collected by the second Charcot Expedition these macrocephalous pedicellariae are rather numerous on the dorsal marginal row. Here, these pedicellariae occur only on the first spines of the dorsal marginal row and the following ones have, in general, one or two ordinary forcipiform pedicellariae that are inserted no longer at the base of the spine, but at a variable height on its first half as we see in various Asterias. When there are two crossed pedicellariae on the same spine, they are inserted at the same level. They can coexist with a macrocephalous pedicellaria place at the base of the spine. As I have said above, these crossed pedicellaria are always smaller than the smallest macrocephalous pedicellariae.

The ventral marginal plates are even more protruding than the dorsal marginals and they form, together, a distinct border that separates the ventral surface from the rest of the body. They correspond exactly to the dorsal marginals, from which they are quite separated and to which they are joined by very regular arcs arranged parallelly, each containing some small plates. Thus are determined the lateral surfaces that are vertical. Each plate has a spine similar to those of the dorsal marginals, but a little smaller, slightly flat, with a round edge with fine asperities. Most of these spines have at their base, a macrocephalous pedicellaria, smaller than those of the carinal row, and, above, one or two ordinary crossed pedicellariae inserted on the spine itself.

Between the small arcs of plates that connect the carinals to the dorsal marginals, we see a regular line of round papulae, absolutely isolated and rather large. We can even see at the base of the arms, the beginning a second row. On the vertical sides of the arms, between the dorsal and ventral marginals, is another very regular row of similar papulae.

The ambulacral grooves are wide and contain four irregular rows of dense tubes.

The adambulacral spines are arranged in two very regular rows. These spines are cylindrical or flat because of their reciprocal pressure. Their end is round. They are covered by a thin integument that makes them appear smooth, but when they are dried, we see they are covered with extremely fine asperities that are close to each other.

On the walls of the groove, we see, from place to place, straight pedicellaria that show nothing in particular, and whose average length is one millimeter (Pl. VI, fig. 3). In the large specimen, there are at the base of the arms, between the adambulacral spines and the row of ventral marginal spines, an intercalated row of spines smaller than the later and that correspond to them rather exactly. The ventral row has a variable development. Sometimes they disappear before the middle of the arm, sometimes they extend a little further. These spines in general lack pedicellariae. I see, however, a crossed pedicellariae on two of them. In the small specimen, this row of spines is nearly completely missing. We find, however, vestiges of them at the base of the arms.

Among the echinoderms that have been collected by the second French Antarctic Expedition of Dr. Charcot that have just been entrusted to me, is found a specimen of Notasterias armata that brings to three the number of specimens presented known of this species. The dimensions are near those of the two specimens from Victoria Land: $\mathrm{R}=20$ to $25 \mathrm{~mm}$. The two rows of dorsal marginal plates are a little nearer the carinal row and the large macrocephalous pedicellariae are a little more abundant. They occur in a rather constant manner at the base of the spines of the dorsal marginal row and I have even found them at the base of some ventral marginal spines, but they are then much smaller. In contrast, the ordinary crossed pedicellariae are very rare. I see some, however, on the spines of the ventral marginal plates. 


\section{OPHIUROIDS}

OPHIOGLYPHA RESISTENS, nov. sp. (Pl. VII, fig. 9 to 12)

Cape Royds. Depth 10-20 fathoms. 1 July 1908. Several specimens.

In the largest specimen, the diameter of the disk is $12 \mathrm{~mm}$ and the arms are only 21 to $22 \mathrm{~mm}$ in length. In general, the arms are a little longer. In a specimen in which the diameter of the disk is only $10 \mathrm{~mm}$, their length attains $28 \mathrm{~mm}$. The body is very robust. The disk is thick. The arms are strong, thick and keeled on the dorsal median line.

The disk is round or sub-pentagonal. The dorsal surface is covered with rather numerous, very unequal thick plates separated by wide grooves. We generally see a large, round centro-dorsal and, outside, a circle of five radials a little smaller than it and widened transversely. These plates are separated from each other by a row of two small round plates. They are also separated from the centro-dorsal by a circle of smaller plates between which are other very reduced plates. Outside this central part are other plates, among which we note, in the radial spaces, a rather large round plate, located at the base of each pair of radial shields and after which follows a row of two or three small plates separating these radial shields from each other. In each interradial space, we see two successive principal plates. The more external one is located toward the periphery of the disk, with the other much smaller plates. The radial shields, of medium size, are triangular with round corners, and a little longer than wide. Their length scarcely exceeds a quarter of the radius of the disk. They are slightly divergent and separated for all their length by the row of plates reported above. We find on their free border, a row of small papillae, round, little developed and forming a regular border in individuals of medium size. In the largest ones, these papillae are more numerous and are arranged in two or even three very irregular rows. They are, moreover, less developed there than in the medium individuals.

We note, in the large specimen, that the radial shields have in their central region, a more or less accentuated depression, while they are raised toward their external border in one or two round protuberances. This arrangement is similar to that I have reported in $O$. anceps, but it is less accentuated. Moreover, most of the plates of the dorsal surface of the disk, especially those that are near the edge, have a tendency to have one or two central protuberances. At the least, they are always more or less convex. Their surface is rugose.

The ventral surface of the disk has, toward the periphery, a rather large rounded median plate, generally wider than long, with some other smaller plates. The genital plates are elongated. They have on their free border, a row of short and little developed papillae. The genital slits are narrow, but they extend from the end of the adoral plates to the periphery of the disk.

The buccal shields are rather large, pyriform or pentagonal, relatively larger in the individuals of medium size than in the large ones. In the latter, they are pyriform with a convex external border. In the medium ones, that are rather pentagonal and have a narrow proximal corner limited by two straight sides and two straight lateral borders connecting by round corners to the convex distal side. They are a little longer than wide. The adoral plates are elongated and narrow, with parallel borders, much longer than wide. The oral plates are likewise elongated and longer than wide, but they are small and a little narrower than the preceding. There are four buccal papillae on each side. 
They are small, low, rectangular and subequal. The unpaired terminal papilla is small and scarcely exceeds the size of the preceding.

The dorsal arm plates are rather large, quadrangular, with a narrow proximal side, a very wide and strongly convex distal side and divergent and straight lateral borders. They are all contiguous. The first ones are a little wider. Then they become as long as wide and finally longer than wide. They are keeled and, moreover, they have, a little behind the distal border, each a large, rounded tubercle that becomes more protruding and more marked as the specimens become larger. These tubercles make the keel of the arm even more apparent.

The first ventral arm plate is rather large, with a round proximal corner and a little convex distal border. It is as wide as long or a little wider than long. The following ones are rather large, triangular with a rather pointed proximal corner, limited by straight sides and a slightly convex distal border. They are wider than long. The first ones are contiguous, but they separate beyond the disk.

The lateral plates, not very prominent, have at the base of the arms, four small papilliform spines. The number falls to three at some distance from the base of the arms, less in smaller specimens. The two ventral spines are very close to each other and the following one is a little more distant than the preceding. The last one is completely dorsal and located at some distance from the third.

The tentacle pores are little developed. Those of the first pair do not open into the mouth. They have, on their external border, three low papillae and, on the internal border, two or three papillae less developed than the preceding, narrower and forming a very thin border in which it difficult to distinguish the limits of the papillae. The pores of the second pair are very small and have two papilliform scales. We still distinguish the pores of the third pair that are very reduced and have two rudimentary scales. Beyond that, the pores do not exist.

Similarities and differences.- - . resistens greatly recalls $O$. anceps that I have described after the specimens discovered by the Scotia at $71^{\circ}$ lat. S. and $16^{\circ}$ long. W. at a depth of 1410 fathoms, but it is clearly distinguished by the more elongated genital slits and by the presence of three pairs of tentacular pores. Although the two last pairs are little developed, they are very visible, while $O$. anceps does not have more than two pairs in all. The dorsal plates of the disk are thinner in $O$. resistens than in $O$. anceps and so their central region is depressed. They do not have, as in this latter species, the peripheral thickening that I have indicated. Finally, the brachial spines are four in number at the base of the arm.

O. resistens is far from O. martensi Studer by the tentacular pores and by the form of the ventral brachial plates.

\section{OPHIOGLYPHA FLEXIBILIS, nov. sp. (Pl. V, fig. 1 and 2}

Cape Royds. Depth, 60-80 fathoms. 20 August 1908. Several specimens.

In the largest individual, the diameter of the disk equals $8 \mathrm{~mm}$ and the arms are 20 to $25 \mathrm{~mm}$ in length. In the others, which are numerous, the diameter of the disk varies between 3 and $6 \mathrm{~mm}$.

The disk is round or sub-pentagonal. The dorsal surface is strongly convex. The ventral surface is flat. The disk is thick while the arms are, on the contrary, very slender, thin and flexible. 
The dorsal surface of the disk is covered with very unequal plates, with clearly indicated edges. We distinguish a large, round centro-dorsal and five primary radials, also rounded and of the same size as the centro-dorsal. The radials are separated from each other by a row of small plates. The circle that they form is also separated from the centro-dorsal by a row of unequal plates, those that correspond to the interval of the radials being much larger than the others. Outside these plates, we see in the radial spaces a triangular plate, larger than the adjacent ones and that separate the proximal regions of the radial shields of each pair. In the interradial spaces, we note toward the periphery of the disk, two very large, round plates, of which the latter occupies the edge of the disk. The other plates are much smaller, unequal and irregularly rounded. The radial shields are small. Their size is less than that of the large plates of the disk. They are triangular, divergent, separated for all their length by two plates, the distal very small, the proximal large and triangular. They are close to each other at the level of their external corner, but non-contiguous in the largest specimens. They are scarcely longer than wide. Their length does not exceed a quarter of the radius of the disk. Outside each shield, we see a row of fairly low papillae, rectangular and obtuse or slightly thin at the end.

The ventral surface has, apart from the large buccal shields, only a few plates. We distinguish a large median plate following the buccal shield and some other smaller plates. The genital plates are narrow. They have on their free edge a row of low papillae. The genital slits are very apparent.

The buccal shields are large, pentagonal in shape, as wide as long. The proximal corner, obtuse, is bordered by two straight sides. The lateral borders are connected by two round corners to the distal side that is convex. The adoral plates are rather small, narrow, two times longer than wide. The oral plates are small and triangular. The lateral buccal papillae generally do not exceed three in number. They are rectangular, rather small. They follow from the internal papillae of the buccal tentacular pore. The unpaired terminal papilla is a little larger than the others.

The dorsal arm plates are rather large. The first ones are rectangular and wider than long, with a very narrow proximal side, two divergent lateral borders and a very wide and strongly convex distal side. It is usually separated into three distinct sides united by obtuse angles. The proximal side is not slow to disappear in the following plates that then become triangular at the same time that they become longer than wide. They are contiguous for the first third of the arms, then they are separated by a narrow interval and they soon become a little longer than wide.

The first ventral arm plate is triangular, a little wider than long, with the proximal corner slightly truncated. The very convex distal border has in its middle a rather wide lobe, more or less apparent, separated sometimes into three small distinct sides. The second plate is rectangular, a little longer than wide, with a narrower proximal side, a wide and convex distal side and divergent lateral edges. The following ones are pentagonal with a sharp proximal corner, and a wide and convex distal border having in its middle a small, more or less pointed lobe. These plates are separate after the third.

The lateral plates, not prominent, each have four short spines, rather wide, conical and pointed, inserting along the length of the distal border of the plate at equal intervals.

The tentacular pores are not very developed. Those of the first pair, that open into the mouth, have on each of their borders three rectangular and obtuse scales. The internal ones are stronger than the external ones. The pores of the second pair have three proximal, external scales, thick, conical, and pointed, and two distal, internal scales, very small, low, and little developed. Those of the third pair have three proximal scales and one or two distal ones. Those of the fourth pair have two or three proximal scales and only one distal scale. Beyond, there is only one proximal scale. 
In the young specimens, the number of dorsal plates of the disk is much less. The six primary plates, with the two large plates of each interradius, are sufficient to cover most of the dorsal surface of the disk. The radial shields are closer outside and sometimes even contiguous for part of their length.

Similarities and differences.-O. flexibilis is near $O$. mimaria that I described after specimens collected by the Scotia at a depth of 1410 fathoms at $71^{\circ} 22^{\prime}$ lat. S. and $16^{\circ} 34^{\prime}$ long. W. It differs from it by its ventral arm plates that rapidly become longer than wide, while in $O$. mamaria they always remain much wider than long, by the ventral surface of the disk that has a large median plate following the buccal shield apart from which there is only a small number of plates, finally by the arm spines that number only four.

It is separated from $O$. martensi Studer, of South Georgia, by a completely different form of the dorsal and ventral arm plates as well as by the tentacular pores and by the presence of four arm spines.

AMPHIURA ALGIDA, nov. sp. (Pl. VII, fig. 14 and 15)

Cape Royds. Depth, 10-20 fathoms. Two specimens.

Cape Royds. Depth, 50-80 fathoms. One specimen.

In the largest individual, the diameter of the disk is $4.5 \mathrm{~mm}$. In the two others, it does not exceed $3 \mathrm{~mm}$. The arms are all broken. They cannot have been more than $15 \mathrm{~mm}$ in length.

The disk is pentagonal with rounded corners. The dorsal surface is covered by large and unequal plates in the form of flat scales, imbricated, whose free edge has a very thin border, finely striated and transparent. These plates are very large in the central region of the disk. They become smaller toward the periphery and toward the radial shields. There is not the least indication of primary plates. The radial shields are small and little developed. They are hardly two and a half times longer than wide. Their length is less than a quarter of the radius of the disk. They are very close together, little divergent and separated by a narrow row of plates.

The ventral surface of the disk is covered with plates identical to those of the dorsal surface, but smaller and equal. The genital slits are narrow.

The buccal shields are triangular with convex sides and a round proximal corner. The distal side is strongly convex. It even has in its middle a lobe that is not very prominent in the large specimen where the shield is nearly as long as wide. In the two small ones, this lobe is, on the contrary, very prominent and the shields are longer than wide. The adoral plates are triangular, with the oral edge slightly curved. They are greatly thinned inside and scarcely contiguous at the mid-line. Sometimes they even remain separated from their counterparts by the proximal corner of the buccal plate. Their external region is, on the contrary, strongly developed and even touch the corresponding region of the opposite plate by compressing the first ventral arm plate. The oral plates are narrow and rather tall. The buccal papillae are first two papillae located on the same plane as the other buccal pieces. The internal one is thick and rounded. The external one is elongated, prominent, rather thick and with an obtuse end. There is, in addition, on the upper plane, a small conical and pointed papilla inserted between the two preceding ones.

The dorsal arm plates are large and triangular with slightly convex sides and a round proximal corner. They are a little wider than long and all are contiguous. 
The first ventral arm plate is very small and triangular, with a sharp distal corner that is bordered on each side by adoral plates. When the latter plates are very close to each other or contiguous, the corner of the plate, pressed between them, is very pointed. When the adoral plates are a little separated, the corner becomes truncated. They following plates are pentagonal, with a proximal corner. On the first plates, that are nearly as long as wide, this corner is first very obtuse. It is narrower on the following plates that become sensibly longer than wide. The distal edge indents slightly beyond the disk. All these plates are contiguous.

The lateral plates have four subequal spines whose length equals that of the article. These spines, rather thick, taper progressively to the end that forms an obtuse point.

The single tentacle scale is well developed. It has two parallel sides and an obtuse end. It is nearly rectangular and nearly two times as long as wide.

Similarities and differences. - A. algida is easily distinguished from all the Anphiura s. str. known possessing scales on the two surfaces of the disk and a single tentacle scale. A. prafecta that I have described after a specimen from Campbell Island, has a remarkably large and stronger tentacle scale than in A. algida. The primary plates are very apparent. The external buccal papilla is squamiform. The ventral surface of the disk is covered with very small scales. A. pusilla Farquhar from New Zealand has six arm spines. Its round tentacle scale is rather small. $A$. magellanica, with its first elongated ventral spine, is very different from A. algida.

Our species is especially near to A. angularis Lyman, but in the latter, the ventral surface of the disk is naked or with rudimentary scales. Moreover, the external buccal papilla is conical and pointed, the tentacle scale is round and the buccal scales are nearly circular.

\section{OPHIODIPLAX, nov. gen.}

This genus recalls Ophiacantha and near genera.

The dorsal surface of the disk is covered with an integument that completely hides the underlying plates, including the radial shields. It has small rods. This integument continues onto the first dorsal arm plates. These are divided, by a transverse suture, into two unequal halves. The proximal one is smaller. This division exists the entire length of the arm. The buccal papillae are numerous. They do not form a regular row.

The division of the dorsal arm plates into two is seen in a very constant way in the numerous specimens that I have been able to study, both in the very young individuals and those whose disk reaches 10 to $11 \mathrm{~mm}$ in diameter and that can be considered as adults. This character is not observed in any known ophiacanthid and it seems to me sufficient to justify the creation of a new genus.

OPHIODIPLAX DISJUNCTA, nov. sp. (Pl. VI, fig. 9, 10, and 11)

Cape Royds. Depth, 60-80 fathoms. 20 August 1908. Three specimens.

The diameter of the disk varies between 8 and $9 \mathrm{~mm}$. The arms attain 40 to $50 \mathrm{~mm}$ in length. The disk is sub-pentagonal in one of the individuals. In the two others, it is pentagonal with more or less concave sides. 
The dorsal surface of the disk is covered with an integument that completely hides the underlying plates. It has small rods, rather separated, short, conical and whose blunt top has two to four or five very fine, pointed spinules. At the periphery of the disk, the rods elongate a little and become cylindrical. Their surface is more or less rugose. They always have some small spinnules at the terminal end. The radial shields are not distinct. They are only indicated by the more or less apparent protuberances of the dorsal surface of the disk at the base of the arms.

The ventral surface of the disk has rods identical to those of the dorsal surface, but thicker than on the latter, especially near the genital slits where we distinguish very fine and rounded plates. These rods continue, decreasing in length, to the area of the buccal shields. The genital slits are very wide.

The buccal shields are very large, quadrangular, wider than long, with rounded corners. The proximal region, which corresponds to the top of the proximal corner, is sometimes separated from the rest of the plate by an irregular groove. The adoral plates are rather wide but not very large. They are scarcely two and a half times longer than wide. They do not have a distal lobe separating the buccal shield from the first ventral arm plate. The oral plates are small and triangular. The buccal papillae are numerous and dense. They do not form a very regular series because, in the middle region, there are two more or less distinct rows. There are about ten in all on each side. These papillae are small, conical and pointed. They become a little longer toward the proximal end of the oral plates. The unpaired terminal plate is a little larger and stronger than the adjacent ones.

The contours of the first dorsal arm plates are not distinct. The integument of the dorsal surface of the disk continues, in fact, for some length of the dorsal surface of the arms in covering the first five or six arm plates. It has rods similar to those of the dorsal surface of the disk, but these are shorter, conical with a rugose end or with two or three small spinules. They become smaller and smaller and finally disappear. The dorsal arm plates appear then and immediately show their characteristic structure. Each of them is, in fact, divided by a slightly convex transverse groove into two unequal parts. The proximal part is small and the distal part is relatively large. Together, these plates have a triangular form. They are a little longer than wide with a round proximal top and a convex distal border. The proximal region of the plate is small, in the form of a triangle with a more or less rounded top. This region is a little longer than wide. The distal region of the plate is wider than long, trapezoidal, with a narrow and slightly concave proximal side, a very wide and convex distal side and two divergent lateral borders.

The first ventral arm plate is rather large and triangular, with round corners. The distal top is round and the proximal base is convex. It is a little wider than long. The following plates are triangular, wider than long, with an obtuse and rounded proximal corner and a strongly convex distal edge. This edge can have a small median obtuse lobe. It is sometimes separated into two distinct sides. These plates are separated from the base of the arm. After the first third, they become longer than wide, with a slightly rounded sharp corner and a distal edge that is always strongly convex.

The rather prominent lateral plates have six spines at the base of the arms. The length of these latter increases slowly after the first, which is equal to the article, up to the third. The fourth and the fifth are a little longer and their length exceeds an article and a half. The sixth is a little shorter. Their surface is covered with very fine rugosities that are a little more marked toward the end. We sometimes find seven spines at a short distance from the base of the arms.

The single tentacular scale is short, thin, spiniform and with a pointed end. 
I have encountered in the collections of the second Antarctic Expedition of Dr. Charcot some specimens of this same ophiuroid that have permitted me to be more accurate in the description of the characters and to assure myself of their constancy. I have noted also some particularities that are good to report. The size of the specimens can be greater than those collected by the English Expedition. In some of them, the diameter exceeds $11 \mathrm{~mm}$. I have represented here two of these individuals. In one, which is seen by the dorsal surface, the diameter of the disk attains barely 9 $\mathrm{mm}$ (Pl. VI, fig. 10). In the other, which is seen by the ventral surface, the diameter of the disk is $11.2 \mathrm{~mm}$ (Pl. VI, fig. 11). The dorsal arm plates are always divided, but their form can have variations: sometimes they are longer than wide as in the individual reproduced in Pl. VI, fig. 10, sometimes, on the contrary, they are a little wider than long. The arms spines can be more developed and the dorsal spine exceeds the length of two articles, as that in the specimen of fig. 10, whose disk is only $9 \mathrm{~mm}$. In the specimens of large size (Pl. VI, fig. 11), the buccal papillae become stronger and more numerous. The ventral arm plates have, after the second, a pentagonal form with a very obtuse proximal corner and a convex distal edge. It is only after the tenth that they become triangular. In a general manner, I note that, in specimens from the Charcot Expedition, the spines of the dorsal surface of the disk continue less far on the arms than on individuals from Victoria Land. They can disappear after the third dorsal arm plate.

O. disjuncta appears to me identical to an Antarctic ophiuroid that J. Bell has figured, without describing it (08, Pl. IV): If it is not identical to this form, it is, in any case, very similar. According to the figures of J. Bell, the dorsal arm plates of this ophiuroid are divided, at the base of the arms, into two unequal parts. But, on the other hand, the tentacle pores would have each two scales, one proximal, the other distal. The scales are widened transversely. I have observed no similar arrangement in my specimens and I wonder if there is not an error in the figures of J. Bell. I shall add that this author considers his ophiuroid as a young. However, in two figures that are made at a magnification of $9 / 4$, the diameter of the disk is $22 \mathrm{~mm}$, measured between the base of an interradial space and the opposite radial edge, which corresponds to a diameter of nearly $10 \mathrm{~mm}$ in natural size. If the numbers are exact, the specimens of Bell would be the size of those that I have studied. It would appear to me to be very difficult to accept that an ophiacanthid, whose disk has an average diameter of $10 \mathrm{~mm}$ is a young.

The scholarly English naturalist appears to attribute to this youth of the specimens, the characters of the dorsal arm plates that are not completely calcified. I am not of this opinion. I think that the plates are perfectly formed and that they remain fragmented in the adult, as we see, moreover, in some other ophiuroids.

\section{ECHINOIDS}

\section{STERECHINUS NEUMAYERI (Meisner)}

(For the bibliography, see Mortensen (10), p. 64.

Cape Royds. Depth, 10-50 fathoms. July 1908. Several specimens of different sizes: the diameter of the test varies between 58 and $24 \mathrm{~mm}$. 
AbatUS SHACKLETONI, nov. sp. (Pl. IV, fig. 3 to10; Pl. VIII, fig 1 to 6)

Cape Royds Bay. 5 March 1908. Depth, 10-20 fathoms. Thirteen specimens of which one is incomplete and broken.

Five specimens are of rather large size. The length is nearly $35 \mathrm{~mm}$. The others are smaller. In the largest, the total length with the spines varies from 34 to $38 \mathrm{~mm}$.

In the individual represented in Pl. VIII, fig. 3 to 5, the dimensions are the following:

$\begin{array}{ll}\text { Length (without spines) } & 36 \mathrm{~mm} \\ \text { Width } & 33 \text { “" } \\ \text { Height } & 19.5 \text { “" }\end{array}$

This individual has very deep incubatory pouches. They are incontestably female. We see by the photographs I have given that its form is regularly ovoid and that the body is rather elongated. This form is seen in three other large specimens. It appears to me to be typical. The last specimen is relatively wider and shorter as we can confirm in the photograph reproduced here (Pl. VIII, fig. 6). The dimensions of this individual are the following.

$\begin{array}{ll}\text { Length (without spines) } & 33 \mathrm{~mm} \\ \text { Width } & 32 \text { “" } \\ \text { Height } & 19 \text { “" }\end{array}$

The incubatory pouches of this specimen are much shallower than those of the preceding, but I consider it nevertheless a female. A third individual, whose test I left intact, has deep incubatory pouches and also appears to be a female. As for the other two individuals with dorsal ambulacra scarcely depressed and not transformed into incubatory pouches, these are males.

The other specimens, of smaller size, have a body relatively widened and less elongated. Their dorsal ambulacra are little depressed and all have the characters of males.

Here are the dimensions I took, spines not included, on seven intact specimens:

$\begin{array}{ll}\text { Length } & \text { Width } \\ 13 \mathrm{~mm} & 11.5 \mathrm{~mm} \\ 16 \text { “ } & 13 \text { “ } \\ 17 \text { “ } & 14 \text { “ } \\ 17 \text { “ } & 15.5 \text { “ } \\ 21.5 \text { “ } & 19 \text { “ } \\ 22 \text { “ } & 19.5 \text { “ } \\ 23 \text { “ } & 19\end{array}$

I shall describe the specimen represented in Pl. VIII, fig. 3 to 5, that I shall take as type of the species. I shall then indicate the differences that I note with that of Pl. VIII, fig. 6. Finally, I shall give the characters of the male.

Seen from above, the test is rather regularly ovoid. It is narrower behind than in front. The greatest width is at the level of the apical system that is nearer the anterior edge then the posterior 
edge. The anterior edge is scarcely depressed in the median line. The groove that corresponds to the anterior dorsal ambulacrum becomes shallower and shallower toward the ambitus. Even the notch that, in the first specimen, is scarcely marked below the fasciole, between the latter and the ambitus becomes, as we shall see later, completely lacking in the second where the groove is, moreover, shallower, as also occurs in males.

Seen laterally, the test has first a curve rising regularly up to the apical system. Then, in reaching this system, it forms a very marked interradial prominence in the specimen lacking spines, but that does not appear or appears only very little on the specimen having its spines. This prominence decreases rapidly up to the posterior end that is vertically truncated and little elevated. The ventral surface is completely flat before the peristome and a little convex behind.

The apical system is located in front of the middle of the body. It has three gonopores, two to the left and one to the right. These pores are round and rather large (Pl. VII, fig. 4). The two pores of the left are very near each other while the right pore is rather separated from the left pore. It is not located exactly at the same transverse level as the latter but is found very slightly behind. The distance between the two pores is $15.5 \mathrm{~mm}$ from the anterior edge of the test and $20.5 \mathrm{~mm}$ from the posterior edge. The madreporite occupies nearly all the space between the two posterior pores. It extends in front nearly to the level of the anterior border of the anterior pore. Behind, it passes the posterior border of the posterior pores. It is riddled with small round pores, regularly arranged and which occupy nearly all the surface. We see, in addition, some very fine granules that are also arranged in a regular manner. We easily recognize the contours of the ocellar plates that are small and pentagonal, with a proximal corner. They each have a transverse pore in the form of a crescent with the concave side turned toward the exterior. The contours of the other plates are indistinct.

The unpaired anterior ambulacrum forms, on the dorsal surface of the test, a rather narrow and shallow groove whose sides continue by a very round border with the interradial regions of the test and that attenuate progressively before reaching the fasciole. It nearly completely disappears at the level of the anterior edge of the test (Pl. VIII, fig. 5). The poriferous zones, located on the slightly oblique sides of the groove, are straight. They diverge somewhat. They are not very separated from each other because of the small width of the groove. I count twenty pores in each of them up to the fasciole. Their size increases from the first up to the seventh, then decreases so that the pores of the two last pairs are very fine. The first eight or ten pairs of pores are separated by two or three granules, often forming a small transverse row. Beyond that, the granules between the pores decrease in size or even completely disappear, while we see appear on each plate a larger granule appear close to its internal border. The pores of the first pairs are arranged following a line perpendicular to the axis of the groove. Then the following pairs are placed obliquely in relation to this axis at the same time that the pores of each pair approach each other and become smaller.

The anterior and posterior lateral ambulacra have nearly the same development. The anterior ambulacra are strongly divergent. They are nearly located on the continuation of each other, while the posteriors are very near each other and little divergent. They are separated by an interradial eminence that I have reported above and whose width at the base is $4 \mathrm{~mm}$. The axis of the anterior ambulacrum forms, with that of the posterior ambulacrum of the same side, an angle of approximately $90^{\circ}$.

The anterior ambulacra are, like the posteriors, very deeply depressed on the dorsal surface of the test. They form the incubatory pouches, elongated but rather narrow in our specimen. They all have the same dimensions. They measure approximately $12 \mathrm{~mm}$ in length and $3 \mathrm{~mm}$ in width. The anterior pouches are slightly widened in the external region, while the posterior pouches keep the same width for their entire extent. The depression that constitutes each pouch is made very abruptly 
after the third pair of ambulacral pores. The walls are nearly vertical. They are connected by a round border with the dorsal surface of the test. The depth of the pouches is $6 \mathrm{~mm}$. The part of the ambulacrum that is between the apical system and the pouch strictly speaking does not remain flush with the test, but is a little depressed, especially in the long direction to form an oblique groove that leads to the pouch. Each pouch extends up to the fasciole. Approaching it, the posterior pouch rises abruptly and the anterior pouch rises a little obliquely.

The dorsal interradial region between the groove and the anterior lateral ambulacrum is convex. It continues insensibly with the groove while it stops abruptly at the edge of the incubatory pouch. It is covered with small primary granules whose size is very uniform and rather spaced. These granules are denser in the area of the incubatory pouch. Their size increases a little at the very edge of the pouch. Between these primary granules are other extremely fine granules. We find these two kinds of granules on the anterior and posterior interradial regions, as well as the posterior interradial prominence. We see that the primary granules always become a little denser and a little larger in the area of the incubatory pouches.

The ventral surface is a little convex (Pl. VIII, fig. 3). The anterior ambulacrum is indistinct. It is slightly depressed in the area of the peristome, but it rises at the same time that it narrows as we approach the edge of the test. It has on each side, four pairs of ambulacral pores, close together, each surrounded by a very apparent oval circle. Here and there is an extremely fine granule. Then the pairs rapidly spread apart while the pores become finer. The granules, on the contrary, suddenly become larger. Their dimensions exceed those of the dorsal granules that they meet at the ambitus. The anterior lateral ambulacra are located on their extensions at the mouth. They have on each side, five pairs of pores each surrounded by their oval circle, forming two convergent rows separated by some fine granules. Then the pores become very fine and spaced, while the granules take the same dimensions as in the adjacent interradius. The posterior lateral ambulacra constitute wide avenues having only very fine and sparse granules. These larger and denser granules appear only in the area of the posterior end.

The anterior and posterior interradial regions of the ventral surface are uniformly covered with rather spaced granules of uniform size, but sensibly larger than those of the dorsal surface with which they are continuous at the ambitus. Between these primary granules we see others that are very fine and sparse. The sternal plastron is simply convex. It is rounded at its posterior end, without forming a prominence or projecting point. It has granules arranged in oblique rows, divergent from its end and directed toward the ventral ambulacra. These granules are at first very fine, but their size increases toward the ambulacra and the peristome.

The peristome is found nearly equal distance between the anterior edge of the test and the middle of the ventral surface. it is rather deeply located, narrow, in the form of a crescent, and rather small. The lip has medium dimensions. Its anterior border is convex. It forms a rather marked protuberance, in the form of a prominent beak that hides most of the peristome. Its lateral border is indented and the posterior border, strongly rounded and convex, extends to the middle of the adjacent second ambulacral plate.

The posterior surface is vertical, but little extended. It is in large part occupied by the periproct (Pl. IV, fig. 6). This, of medium size, has a little irregular ovoid form. It is a little higher than wide and measures $5.1 \mathrm{~mm}$ by 4.6. It has a peripheral row of large, rectangular plates and two more or less regular circles of smaller central plates. There is not the least indication of ambulacral tubes in the area of the periproct.

The fasciole has a rather regular contour, without inflexions or well-marked sinuosities (Pl. IV, fig 6; Pl. VIII, fig. 4 and 5). It is very near the ambitus between the anterior ambulacrum and the 
anterior incubatory pouch to the end of which it is tangent. In this path, it has the form of a kind of a nearly regular circle, except for two very slight sinuosities. Between the two incubatory pouches on each side. the fasciole progressively separates from the ambitus and becomes slightly concave. At the level of the end of the posterior pouch, to which it is equally tangent, it has a very marked obtuse angle and is directed toward the posterior interradius following a direction nearly parallel to the posterior edge of the test. It remains separated from the edge by an interval of approximately $4 \mathrm{~mm}$. The fasciole keeps the same widgth for all its path, approximately $1.5 \mathrm{~mm}$.

The primary tubercles are perforated and finely crenelated. They are smaller on the dorsal surface and larger on the ventral surface. Their dimensions remain uniform on nearly the extent of the dorsal surface except for the immediate area of the incubatory pouches, where they become a little larger. On the ventral surface, they are more spaced and larger. But their size decreases as we move away from the peristome and they pass progressively to granules on the dorsal surface. In the midst of these primary granules are other very fine ones, whose dimensions remain uniform on the two surfaces of the test.

The spines of the dorsal surface are fine and rather short. Their length does not exceed $3 \mathrm{~mm}$. They lie on the test forming a dense felting. They are cylindrical, obtuse at the end and, toward the ambitus, slightly curved. The spines of the edges of the incubatory pouches are longer, a little flat and directed in a manner to cover the pouches that are scarcely visible on the specimens with spines. The spines of the ventral surface are well developed. Their length can attain $5 \mathrm{~mm}$.

The pedicellariae belong to three types: tridactyl, rostrate and globiferous. The tridactyls are of two different forms, but always with three valves. Some recall those that Mortensen has described and figured in A. cavernosus (10 bis, Pl. XIX, fig. 37). The valves are enlarged in the form of spoons that are little narrowed at their base and that touch each other for much of their length. These edges have extremely fine and regular teeth. The pedicellariae of the second form have narrow, curved valves, separated for most of their length and contiguous only in the terminal part that is enlarged and with sharp teeth. This form thus approaches rostrate pedicellariae. These two kinds of pedicellariae occur over all the test. The first is more abundant than the second. Both attain a rather large size. The length of the head can be 0.5 to $0.6 \mathrm{~mm}$.

The rostrate pedicellariae resemble those that Mortensen has indicated in A. cavernosus (10 bis, Pl. XXIX, fig. 30, 38 and 45). They have strongly curved valves that, except for the triangular base, remain narrow, tapering very little to their end that is obtuse. They edges lack teeth, but they are a little sinuous. They rise, here and there, into a little protruding tooth. The end of the valve is not toothed. These pedicellariae are rarer than the preceding. The generally remain smaller. The length of their head however reaches 0.3 to $0.4 \mathrm{~mm}$.

The globiferous pedicellariae are especially found in the area of the periproct. They greatly recall those that I have described and figured in A. elongatus $(\mathbf{0 8}, \mathrm{p}$. 620, Pl. XVI, fig. 154). The valves are more curved than in this latter species. They end, as in it, in two extremely developed hooks, behind which is an elongated slit, after which comes a short tubular part. These valves resemble also those of globiferous pedicellariae described by Mortensen in the variety bidens of A. cavernosus, but here, the slit preceding the two terminal hooks is more elongated. The calcareous stem has, a little before its end, a very slight thickening, sometimes scarcely marked. The valves and the distal end of the stalk are covered, as in A. elongatus, by a strongly pigmented and glandular tissue that makes the head of the pedicellaria very apparent. The ensemble measures approximately one millimeter in length, while the values enclosed in this covering do not exceed $0.35 \mathrm{~mm}$. 
The spicules of the ambulacral tubes are small and very irregular in form. The simplest has the form of more or less curved and rather thick rods width a variable number of lateral extensions in the form of teeth. When these extensions are joined, small, perforated plates are formed that are elongated and very irregular in form.

The large specimens have a fairly dark and uniform color. Small ones are paler brown. Some of them are simply grayish.

The specimen shown in Pl. VIII, fig. 6, differs by some characters from those that I just described. As I said above, the test is relatively wide at the level of the apical system and nearer the anterior edge. The line that joins the two posterior gonopores is $13 \mathrm{~mm}$ from the anterior edge and $20 \mathrm{~mm}$ from the posterior edge of the test. The gonopores are a little smaller than in the type. The anterior groove is shallower and the anterior edge of the test is no longer depressed in the middle. The ambulacral pores of the groove are finer. The dorsal interradial prominence, which separates the two posterior ambulacra, is also less pointed. Finally, the periproct is a little smaller. It is sensibly higher than wide. It measures $5 \mathrm{~mm}$ in height and 4.5 in width. It approaches a little the form that we see in the male. The tubercles of the dorsal surface of the test are more uniformly distributed than in the type. The difference in size that we saw with those adjacent to the lateral ambulacra is less apparent.

The anterior and posterior lateral ambulacra of the dorsal surface are rather strongly depressed, but these are much shallower than in the type. Their depth does not exceed $3.5 \mathrm{~mm}$. Instead of appearing abruptly and having an abrupt and vertical proximal edge, the depressions progressively deepen by the gradual sinking of the ambulacra. I count nineteen pairs of pores in the anterior ambulacrum from the proximal end of the ambulacrum to the fasciole, and twenty in the posterior ambulacrum. The left posterior depression is not single or continuous. It is rather formed by two successive depressions separated by a shallower region. This arrangement is evidently accidental because it does not exist on the right side.

Although the incubatory pouches are less developed in this specimen than in the preceding, it exists, however. It does not appear to me to be doubtful that the specimen is a female. The arrangement of the dorsal ambulacra is in fact very different in the male that remains for me to describe.

I have studied the characters of the male in two specimens of slightly different size. The respective dimensions without spines are the following:

$\begin{array}{lll}\text { Length } & 34 \mathrm{~mm} & 29.5 \mathrm{~mm} \\ \text { Maximum width } & 30 \text { “ } & 27 \text { “ } \\ \text { Maximum height } & 15 \text { “ } & 18.5 \text { “ }\end{array}$

I show here the larger individual (Pl. IV, fig. 3 to 5).

The test is a little wider and shorter than in the female that serves me as the type for the description of the species. But this character should not be linked to a difference in sex, as we have seen above. In the two individuals, the dorsal anterior ambulacrum is scarcely depressed. It is flush with the test and reaches the internal border of the fasciole. The first fifteen pore pairs alone are rather developed. The following ones are scarcely apparent. The pores are relatively a little larger in the smaller specimen than in the other. The anterior and posterior lateral ambulacral are weakly depressed. The anterior ambulacra are a little deeper than the posteriors, but the difference is little 
sensible. The depression begins from the first pores pairs in the posterior ambulacra and only after the second or third in the anteriors. I count twenty pore pairs in each of these ambulacra.

The gonopores are small. In the large individual, the two left pores are very elongated, nearly two times longer than wide. Their large axis is oriented following the direction of the interradius. They are consequently directed obliquely in relation to each other. The right pore is, on the contrary, nearly circular and smaller than the two others. The internal edge of this pore is separated from the internal edge of the left posterior pore by $1.7 \mathrm{~mm}$.

In the small specimen, the three gonopores are small and circular. The right pore is more separated from the left pore than in the other individual because it is separated by $2 \mathrm{~mm}$. The madreporite is only a small, round perforated plate, around which are some tubercles, while in the large individual, this plate has the structure I have described above in the female.

The fasciole has also the same path as in the latter, but in the small specimen, its sinuosities are scarcely marked.

The periproct is much higher than wide. It measures $4.7 \mathrm{~mm}$ in height by 3.5 in width in the large specimen, and 4.4 by $3 \mathrm{~mm}$ in the small one. It is thus comparatively a little higher in the latter.

I ask Sir Ernest Shackleton, Commander of the English Antarctic Expedition, to accept the dedication of this species.

Similarities and differences.-Mortensen recently has specified the respective limits of the genera Hemiaster and Abatus. He has made a revision of the species belonging to the latter, species that are all southern. Because of the constitution of the apical system, A. Shackleton belongs to the Ethmolysii of Loveno. Consequently, it should be placed with the genus Abatus, as Mortensen accepts. The Danish naturalist schoolar has rendered zoologist a very great service in fixing the characters of the different species of the genus Abatus, species that had been more or less confused by authors because of insufficient descriptions that had been given them. His investigation has led him to consider, as distinct, the four following species:
Abatus cordatus (Verrill)
Abatus agassizii (Pfeffer)
Abatus cavernosus (Philippi)
Abatus philippii Loven.

As for A. elongatus that I described under the name Hemiaster elongatus, Mortensen has united it with A. agassizii.

A. cordatus comes from the Kerguelen Islands. The three following species all belong to the southern end of South America. A. elongatus has been encountered in the South Orcades.

A. shackletoni lacks sub-anal ambulacal tubes, a character it shares with A. cordatus and agassizii. It is thus distinguished immediately form A. philippi and cavernosus that have, moreover, a very marked dorsal groove. It is especially separated from A. philippi by the four dorsal petals that are deeply sunken and form equally developed incubatory pouches.

The characters of $A$. cordatus have been well established by Mortensen. This species is completely endemic to the Kerguelen Islands. It does not penetrate into the South American region. A. shackletoni is distinguished easily from it by the presence of globiferous pedicellariae, by the shallower dorsal anterior groove, by the incubatory pouches that are narrower and comparatively 
longer, by a different form of the body that is more elongated and by the apical system that is previously described.

The location of the apical system also permits separation of A. shackletoni from A. agassizii in which this system is central. The test is more elongated and the peristome is smaller in the first species. Finally, the pedicellariae are different. I have not seen, on the internal surface of the valves of tridactyl pedicellariae of $A$. shackletoni, this median projection formed by the mesh of the network that Mortensen has indicated in A. agassizii.

The elongated form of $A$ schaletoni recalls that of $A$. elongatus. Leaving aside the question asked by Mortensen, if $A$. elongatus should be united or not with $A$. agassizii, it is certain that $A$. shackletoni cannot be confused with the first species. It is separated from it by its apical system moved forward, by the larger periproct and by a different form of the tridactyl and rostrate pedicellariae.

The spicules of the ambulacral tubes have no particular character. They are curved rods with unequal lateral teeth that can be elongated and united to form small, irregular, perforated plates.

I am happy to thank here my excellent friend, Dr. Th. Mortensen, for the examination that he has kind enough to make of this Abatus as well as the genus that I describe below. He has had likewise the extreme kindness to send to me the proofs and plates of his memoir, still in press when I wrote these lines: Echinoidea of the Swedish South-polar Expedition, in which he studied the Antarctic spatangoids and that has given me the greatest service for my comparisons.

To the specimens that I have indicated above, there are to be added five more specimens, extremely young, whose length varies between 5 and $12 \mathrm{~mm}$, and that I likewise report as $A$. shackletoni. These specimens were associated with six other irregular urchins of similar dimensions and that I consider as belonging to the genus Brisaster. These are perhaps $B$. antarcticus Sladen, but they are too young to be determined with certainty. They have only some non-characteristic pedicellariae. I report them here only for the record. 
PSEUDABATUS, nov. gen.

This genus is close to the genus Abatus that it recalls by the constitution of its apical system in which the madreporite separates widely the two posterior genital plates, but it differs from it by the condition of the incubatory pouches. While in the genus Abatus, they begin at the apical system or a very short distance behind, here the pouches form at some distance from the apical system, after the eight or nine pore pairs. There remains, thus, between the apical system and each of the incubatory pouches, a part of the ambulacra non-modified and completely flush with the test, while the depression that forms the pouch is made very abruptly. Its external edge is near the fasciole. The anterior ambulacrum also remains flush with the test. The gonopores number three. The posterior surface is not vertical but is directed obliquely forward of the ventral side so that the periproct, that it has, is sub-ventral. In the only species known, the pedicellariae belong to three types: didactyl, rostrate and globiferous. The tridactyls are completely missing and the globiferous pedicellariae are of a particular form, their valves having the end rounded and with small teeth.

Although the genus Pseudabatus is near the genus Abatus, it has appeared necessary to me to separate it because of three principal characters indicated above: position of the elongated incubatory pouches separated from the apical system, condition of the periproct and form of the pedicellariae.

Pseudabatus NIMRODI, nov. sp. (Pl. VII, fig. 1 to 8; Pl. VIII, fig. 7 to 12)

Cape Royds Bay. June 1908. Depth, 7-20 fathoms. Two specimens.

The two specimens are not in a perfect state of integrity. They have breaks, either on the ventral surface or on the sides of the test. They are nevertheless very sufficient to permit a complete study. They both have nearly the same dimensions, which are the following: length, $49 \mathrm{~mm}$; width, 43 $\mathrm{mm}$; height, $27 \mathrm{~mm}$.

In one of the individuals, which I shall call individual A and that is shown in Pl. VII, fig.1 and Pl. VIII, fig. 8, 10 and 12, the dorsal surface of the test has, when we regard the urchin from the side (Pl. VII, fig. 1), a regular curve both in front and behind the apical system so that the contour of this surface is regularly rounded. The other individual, or individual B (Pl. VIII, fig. 9), has, in the front part of the dorsal surface, a simply oblique profile and little convex. The posterior interradial region is slightly prominent so that the test, seen laterally, is more conical than in the other specimen. In both of them, the apical pole is flat.

Seen from the dorsal surface (Pl. VIII, fig. 7 and 8), the contour of the dorsal is oval but it is not perfectly regular in either of the two specimens. The right side of the anterior edge of the test is a little more prominent than the left side. The anterior border does not have the least trace of a notch in its middle because the anterior ambulacrum is flush with the test.

The ventral surface is nearly flat. The unpaired posterior interradius is very slight convex. The anterior edge of the lip is $15.5 \mathrm{~mm}$ behind the anterior edge of the test in individual A. The measurement could not be made on individual B whose ventral surface is broken in the central part.

In examining the profile of specimen $A$, we see that the upper edge of the dorsal surface is connected to the ventral surface by a small, very short and oblique posterior surface. In specimen $\mathrm{B}$, this surface is a little higher and less oblique. As a result, in the first the periproct is in part 
located on the ventral surface and is visible when we regard the urchin by this surface (Pl. VIII, fig. 12). In the second, it appears very little on the ventral side. Moreover, in individual A, the periproct is rather small. It measures $5 \mathrm{~mm}$ in diameter. It is nearly as high as wide. Its contour is irregularly circular with a small point on its ventral side (Pl. VIII, fig. 10). In individual B, the periproct is larger. It measures $6.5 \mathrm{~mm}$ in width by 6 in height. Its contour is also irregularly round (Pl. VIII, fig. 11).

The apical pole is closer to the anterior edge of the test than the posterior edge. The line that connects the centers of the two posterior gonopores is $20 \mathrm{~mm}$ from the anterior edge and $29 \mathrm{~mm}$ from the posterior edge of the test. The three gonopores of specimen A are slightly ovoid and nearly as large as in the second. They measure $1.7 \mathrm{~mm}$ in width. The centers of the two anterior pores are separated by a distance of $6 \mathrm{~mm}$ (fig. 8). In specimen B, the pores are $1.2 \mathrm{~mm}$ in width. The centers are separated by a distance of $5 \mathrm{~mm}$ (fig. 7).

The contours of the plates of the apical system are easily recognizable, especially in specimen B (Pl. VII, fig. 4). In the latter, the two left genital plates are one and a half times longer than wide. The pore of each is much nearer the external edge than the internal edge. There are some small tubercles outside and inside the pore. These plates are separated, over half of their length, by the ocellar plate of the left anterior ambulacrum. The right genital plate is smaller than the two others and hard longer than wide. The pore is located nearly equal distance from the external border and the internal border. The madeporite, which separates the two left genital plates from the right plate, is elongated and narrowed in its anterior region. It passes in front of the middle of the anterior ocellar plate and stops behind at the level of the middle of the two posterior ocellar plates. It has pores, small and not numerous, irregularly arranged, especially in its middle region, while on the rest of its surface, it has small tubercles. The ocellar plates are triangular with a round internal border and a more or less concave external border toward the middle of which is the pore that is elongated in the radial direction. These plates are more projecting than the ambulacra that they end. The ocellar plate of ambulacrum IV, which is located between the external halves of the two left genital plates, with the proximal corner more pointed and less round than the others. It is the only one that is not contiguous with the madreporite.

In individual A (Pl. VIII, fig. 8) I see, in the characters of the apical system, some differences that are not due to a difference in sex because I recognize eggs in the incubatory pouches of both. The gonopores are a little larger and separated than in specimen B. They are also slightly oval. The genital plates have more numerous tubercles. The ocellar plates are not protruding. They are narrower and relatively a little more elongated than in individual B. Their contours are less distinct. The madreporite has pores only on a small central area. All the rest of its surface is covered with small secondary tubercles.

The unpaired anterior ambulacrum remains absolutely flush with the test in individual A (Pl. VIII, fig. 8). It has, in the proximal half, a very slight tendency to be depressed in the second individual (fig. 7). The poriferous zones are straight and parallel. Each of them has twenty-two pore pairs counting up to the fasciole. The pores of the first three or four pairs are very fine, very near each other and arranged obliquely in relation to the axis of the ambulacrum. The following ones are larger, more separated and placed transversally. After the seventeenth or eighteenth pair, the pores approach each other again obliquely. They become very small. The pores are near the anterior and external edges of the plate. Some small, very fine tubercles occur either between the internal edge or between the posterior edge and the plate and the pore pair. Among the internal tubercles, we often note one larger than the others. As we approach the fasciole, the number and size of the tubercles increases. Each plate develops some small primary tubercles. Beyond the 
fasciole, these primary tubercles become more numerous and denser. Between them are much finer tubercles.

The anterior lateral ambulacra are very strongly divergent. On the contrary, the posterior ambulacra are very near each other. The anterior ambulacrum forms, with the posterior ambulacrum of the same side, a nearly right angle.

The anterior ambulacrum begins by a thin part that enlarges and remains absolutely at the level of the test, without the least tendency to sink until the ninth pair of pores. At that level, the ambulacrum abruptly sinks at the same time that it widens. It does not follow in sinking only a vertical direction, goes obliquely inward toward the apical pole so that the incubatory pouch thus formed is in reality longer than it appears from the outside. Its thin internal border overhangs a portion of the pouch that can attain approximately $3 \mathrm{~mm}$ in length. The incubatory pouch has the following dimensions.

\begin{tabular}{lccc} 
& \multicolumn{2}{c}{ Specimen A } & Specimen B \\
Exterior length & $11 \mathrm{~mm}$ & $14 \mathrm{~mm}$ \\
Exterior width & 5.5 “ & 6 “ \\
Maximum depth & 6 & 8 & 8.9 “
\end{tabular}

Toward its outer third, the pouch narrows and its bottom rises progressively to reach the level of the test. It ends at nearly the internal border of the fasciole in specimen B, while in the other it does not reach exactly the border. There remains at least flush with the test an ambulacral plate that separates the pouch from the fasciole and elevation of the pouch is more progressive.

The posterior ambulacra have similar arrangements. The pouch, which is formed abruptly, and whose internal surface is likewise directed obliquely inward, is separated from the apical system by a non-modified ambulacral part and remains flush with the test on which I count nine pairs of pores in individual B and eight in the other. In the first, the pouch is little larger. The pouches have the following respective dimensions.

$\begin{array}{lrc} & \text { Specimen A } & \text { Specimen B } \\ \text { Exterior length } & 14 \mathrm{~mm} & 14 \mathrm{~mm} \\ \text { Exterior width } & 5 \text { “ } & 6 \text { “ } \\ \begin{array}{l}\text { Maximum } \\ \text { depth }\end{array} & 9 \text { “ } & 9 \text { “ }\end{array}$

The posterior pouches are thus a little larger than the anterior. In specimen B, they extend to the internal edge of the fasciole, while in the other individual, they are separated from the edge by one or two plates flush with the test, as happens for the anterior pouches. The plates that form the walls of the pouches have small tubercles with small spines, fine and cylindrical, in the middle of which I have found some eggs in the two individuals.

Beyond the pouches, the ambulacral plates are uniformly covered with primary tubercles mixed with other much finer tubercles. The interradial regions of the dorsal have likewise a uniform covering of dense primary tubercles, between which are fine granules. The posterior interradius is simply convex without forming a protuberance.

The ventral surface is slightly convex (Pl. VIII, fig. 12). The peristome is rather wide. The anterior edge of the lip is projecting and wide, but it is rounded and protrudes a little forward. It leaves uncovered most of the plates of the peristome. It has been absolutely impossible for me to 
recognize, in the specimen where it is preserved, the posterior borders of the lip, even after treatment with bleach.

The ventral anterior ambulacrum is slightly depressed. It is rather large in the area of the peristome. Then it narrows and rises in approaching the anterior edge of the test. It has, on each side, five ambulacral pores each located at the edge of a rather marked oval depression. The anterior lateral ambulacra are nearly located on the extension of each other. They are depressed in their proximal region, a little more than the anterior ambulacrum, but they return to the level of the test toward the middle of their length. Each of them has, on each side, five or six pores with their oval depressions.

The posterior ambulacra are wide. They are a little depressed only in the immediate area of the peristome. Each of them has two slightly divergent rows of four or five pores with their oval depressions. The following plates, very large, have as usual, a small pore located toward the anterior edge.

The ambulacra have only some very fine, sparse tubercles on the anterior ambulacra, denser on the posterior ambulacra. The primary tubercles begin to appear only in the area of the edge of the test. The ventral interradial regions have some primary tubercles sensibly larger than those of the dorsal surface, with some very fine tubercles that generally form a circle around the preceding. The tubercles of the posterior interradius are not more developed than the others. They form more or less regular rows. They diverge after the posterior corner that begins with tubercles first small that then enlarge toward the ventral ambulacrum or the peristome.

I said above that in specimen $\mathrm{A}$, the posterior end is slightly rounded, while in the second, the end is better marked and forms a small surface directed obliquely downward. Also, the periproct is more visible by the ventral surface in specimen A than in specimen B, although it is smaller in the first. The plates that cover the periproct are irregular in shape and arrangement. They are larger toward the periphery. There is no trace of sub-anal ambulacral tubes.

The fasciole is located very near the anterior edge of the test from which it is separated by barely a distance of $5 \mathrm{~mm}$. But, as the dorsal surface bends very rapidly forward to join the ventral surface and finally unites with this surface by a nearly vertical part. As, on the other hand, the fasciole is found located on this nearly vertical part, it is scarcely visible when we look at the animal from above. After a short path parallel to the edge of the test, the fasciole separates slightly and has two shallow indentations separated by a sharp corner. It then reaches the external edge of the anterior incubatory pouch that it goes around and bends first inward, parallel to the posterior edge of the pouch. It is not slow in forming an obtuse angle to retake its path parallel to the edge of the test from which is rather separated between the two incubatory pouches. Then, reaching approximately 7 or $8 \mathrm{~m}$ from the posterior pouch, it forms a new obtuse angle, approaching the edge of the test, goes around the external edge of the posterior incubatory pouch and is directed toward the median interradial line in remaining approximately $8 \mathrm{~mm}$ from the posterior edge of the test. Its average width is approximately one millimeter. It narrows slightly in its anterior and posterior parts and widens a little at the level of the two incubatory pouches.

The primary tubercles are not very protruding. They are larger on the ventral surface than on the dorsal surface as I have had the occasion to say. But their dimensions remain very uniform in the same region. They only become a little larger of the anterior and posterior edges of the incubatory pouches. They are perforated and finely crenelated.

The spines on the primary tubercles of the dorsal surface are very short, fine and dense, separated by other much smaller spines. They are a little flattened and widened into a spatula, with a truncated end and a finely striated surface. They become a little stronger at the ambitus. Toward 
the incubator pouches, the spines become wider and stronger. Their end is enlarged and they become directed horizontally to entangle with their counterparts from the opposite edge in a way to cover the pouch. These spines, as well as the marginal spines often have a very marked longitudinal groove. The spines of the ventral surface are more developed than on the dorsal surface. They are elongated, flattened, widened at the end. The largest have grooves.

The pedicellariae belong to three types: didactyl, rostrate and globiferous. The didactyl pedicellariae are abundantly distributed on all the test (Pl. VII, fig. 6 and 7). Their stalk is relatively rather long and the calcareous stem is separated from the head by a distance that is nearly equal to the height of the latter, which varies between 0.6 and $0.7 \mathrm{~mm}$. The valves are flat. Their base has a deep notch. Their external surface is convex. Inside, it leans against its counterpart by a straight border with extremely fine and very regular teeth. The perforations are arranged regularly. The tridactyl pedicellariae, which these replace, are completely missing.

The rostrate pedicellariae are also very abundant (Pl. VII, fig. 8). Their head measures 0.8 to 1 $\mathrm{mm}$ in height in the largest and the calcareous stem of their stalk, widened at its end, is very near it. Their valves have an elongated base. The blade is narrow. It keeps nearly the same width to the end that is a little widened. The edges are rolled inward. They are a little irregular, sinuous. They have some teeth, very small, low, and very spaced, while the end has a row of very fine teeth, close together and very regularly arranged.

The globiferous pedicellariae are very rare (Pl. VII, fig. 5). Their head, which measures 0.4 to 0.5 in height, is covered with a dark glandular integument similar to that we encountered in the genus Abatus. The valves are formed of a delicate calcareous tissue with large perforations. They have an elongated blade, rather wide and widening slightly to the end. It is round and has ten to twelve teeth, conical, pointed, rather short, contiguous, a little unequal and forming a border the entire length of the blade. The very wide opening passes the middle of the blade. Below it, the latter constitutes a tube whose walls have large perforations.

The color of the two specimens was a nearly uniformly black. To study them and photograph them, I had to discolor them incompletely with bleach. But the test has kept some spots and mottling, so I have experienced great difficulties in obtaining acceptable photographs.

LYON, September 1910.

\section{LIST OF CITED WORKS}

91. Perrier, Ed, Échinodermes de la Mission du Cap Horn. Paris, 1891.

95, Leitpold, Fr. "Asteroidea der Vettor Pisani Expedition" Zeit. für wiss. Zool., Bd. LIX.

03. Ludwig, H. . Résultats du Voyage du S.Y. "Belgica," Seesterne.

05." . "Asterien und Ophiuren der schwedischen Expedition nach den Magalhaenslindern, 1895-97." Zeit. für wiss. Zool., Bd. 82.

06. Fisher, W. K. The Starfishes of the Hawaïan Islands. U.S. Fish Commission Bulletin for 1903, Part III. Washington, 1906.

06.Kœhler, R.. Expédition antarctique francaise commandée par le Dr. J. Charcot. Échinodermes.

08. “. " Astéries, Ophiures et Échinides de | Expédition Antarctique Nationale Ecossaise.” Trams. Roy. Soc. Edinburgh, vol. xlvi.

08. Bell, J. . "National Antarctic Expedition," Natural History, vol. iv.: Echinoderma.

10. Mortensen, Th. "Die Echinoiden der deutschen südpolar Expedition, 1901-03," Deutsche südpolur Expedition, xi,: Zoologie, ili.

10bis. " South-polar Expedition, vol. iii.: Echinoidea. 


\section{PLATE IV}

Fig. 1.-Cryaster antarcticus. Dorsal surface reduced approximately five times.

Fig. 2.-Cryaster antarcticus. Ventral surface reduced approximately five times.

Fig. 3.-Abatus shackletoni, male. Lateral view. Magnification 1.6.

Fig. 4.-Abatus shackletoni, male. Posterior surface. Magnification 1.6

Fig. 5.-Abatus shackletoni, male. Dorsal surface. Magnification 1.6.

Fig. 6.-Abatus shackletoni, female. Posterior surface. Magnification 1.5.

Fig. 7.-Abatus shackletoni. Valve of a tridactyle pedicellaria with wide values seen in profile. Magnification 60.

Fig. 8.-Abatus shackletoni. Same valve seen from three quarters. Magnification 60.

Fig. 9.-Abatus shackletoni. Valve of a rostrate pedicellaria seen by the external surface. Magnification 80.

Fig. 10.-Abatus shackletoni. Valve of a rostrate pedicellariae seen by the internal surface. Magnification 80.

Fig. 11.-Abatus shackletoni. Valve of a globiferous pedicellaria. Magnification 110.

Fig. 12.-Abatus shackletom. Valve of a tridactyl pedicellaria with narrow valves. Magnification 60. 
R. KOHLER : ÉCHINODERMES

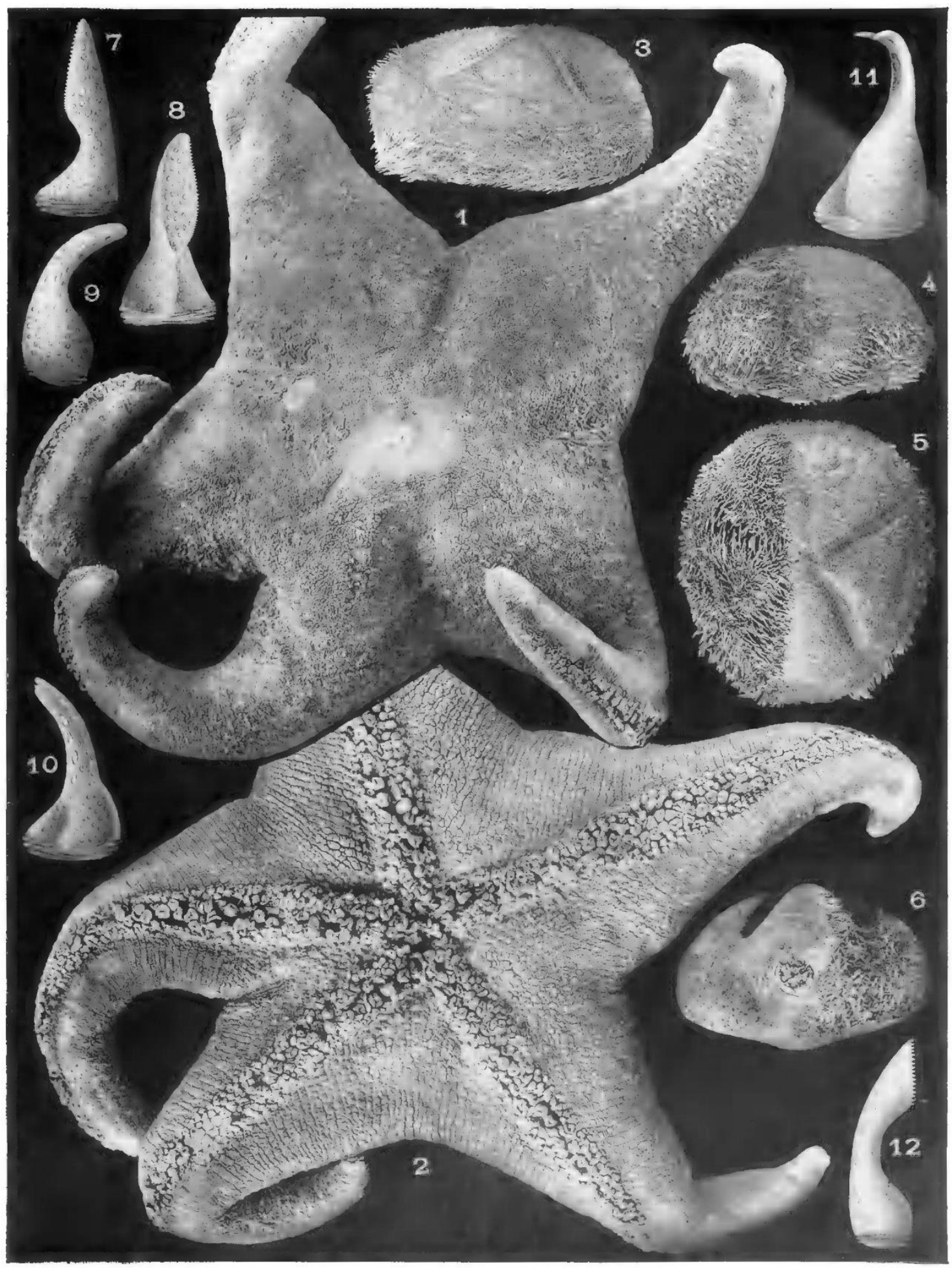

1R. livehler fecit 


\section{PLATE V}

Fig. 1.-Ophioglypha flexibilis. Dorsal surface. Magnification 4.

Fig. 2.-Ophioglypha flexibilis. Ventral surface. Magnification 4.

Fig. 3.-Coscinasterias victoria. Dorsal surface. Magnification 1.2.

Fig. 4.-Coscinasterias victoria. Ventral surface. Magnification 1.2.

Fig. 5.-Coscinasterias brucei. Young individual seen by the dorsal surface. Magnification 1.8.

Fig. 6.-Notasterias armata. Macrocephelous pedicellaria seen in profile. Magnification 265.

Fig. 7.-Notasterias armata. Macrocephalous pedicellaria see in profile after treatment with potassium that separated the two valves and the basal piece. Magnification 25.

Fig. 8.-Notasterias armata. Valve isolated from a small macrocephalous pedicellaria. Magnification 40.

Fig. 9.-Notasterias armata. Second valve of the same pedicellaria. Magnification 40.

Fig. 10. - Notasterias armata. Basal piece of the same pedicellaria. Magnification 40.

Fig. 11. - Notasterias armata. Valve of another macrocephalous pedicellaria a little larger than the preceding. Magnification 30 
R. KOEHIER : ÉCHINODERMES

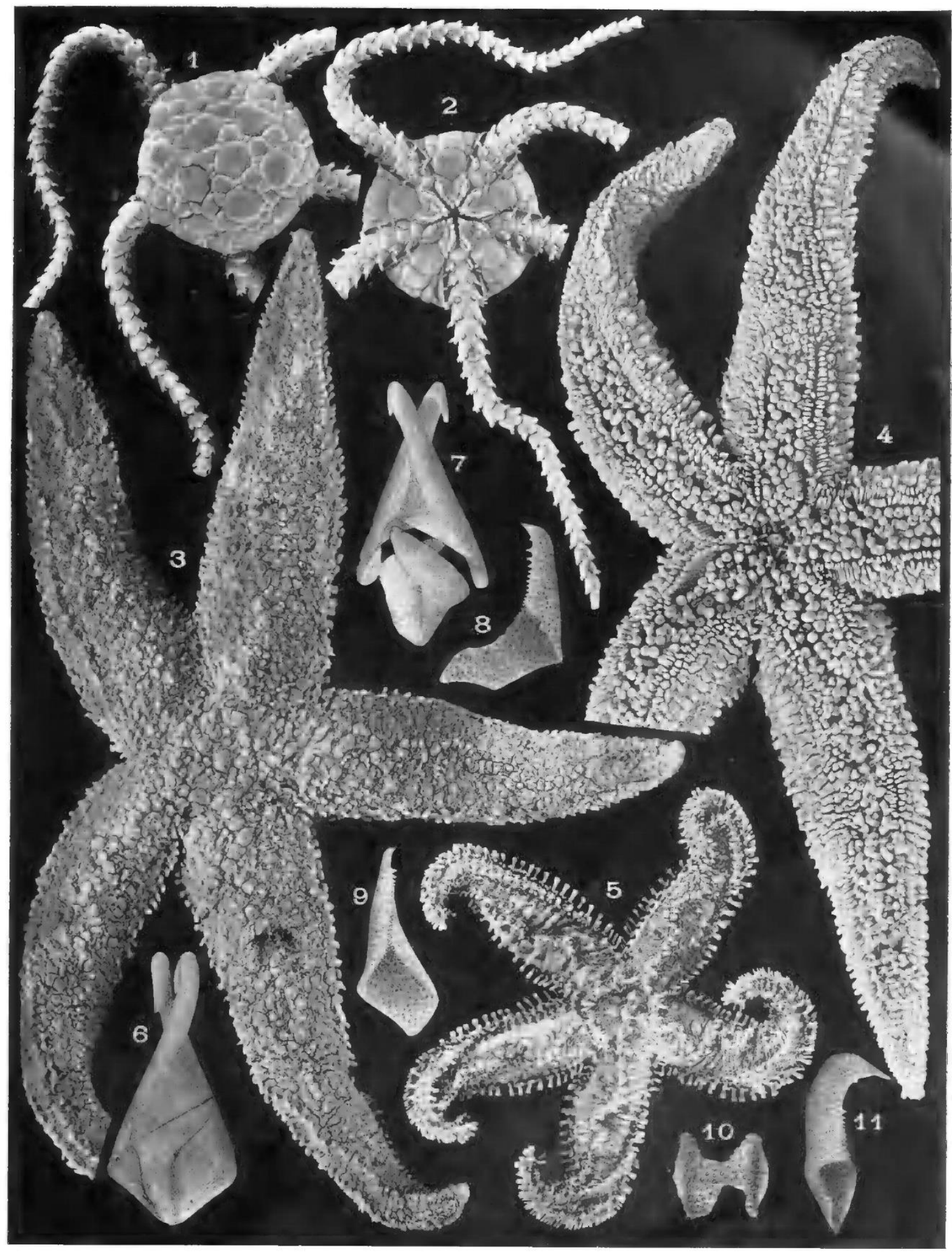

R. Koehler fecit 


\section{PLATE VI}

Fig. 1.-Notasterias armata. Ventral surface of the largest specimen. Magnification 2.

Fig. 2.-Notasterias armata. Dorsal surface. Magnification 2.

Fig. 3.-Notasterias armata. Straight pedicellaria of the ambulacral groove. Magnification 35.

Fig. 4.-Notasterias armata. Large entire macrocephalous pedicellaria seen from the front. Magnification 20.

Fig. 5 to 7.-Notastervas armata. The two valves and the basal piece of a large macrocephalous pedicellaria. Magnification 20.

Fig. 8.-Notasterias armata. Macrocephalous pedicellaria of medium size seen from the front. Magnification 35.

Fig. 9.-Ophiodiplax disjuncta. Specimen collected by the English Antarctic Expedition; dorsal surface. Magnification 4.

Fig. 10.-Ophiodiplax disjuncta. Specimen collected by the second Expédition Antarctique of Dr. Charcot; dorsal surface. Magnification 4.

Fig. 11.-Ophiodiplax disjuncta. Ventral surface of the same specimen. Magnification 4. 
R. KEHLER : ECHINODERHES

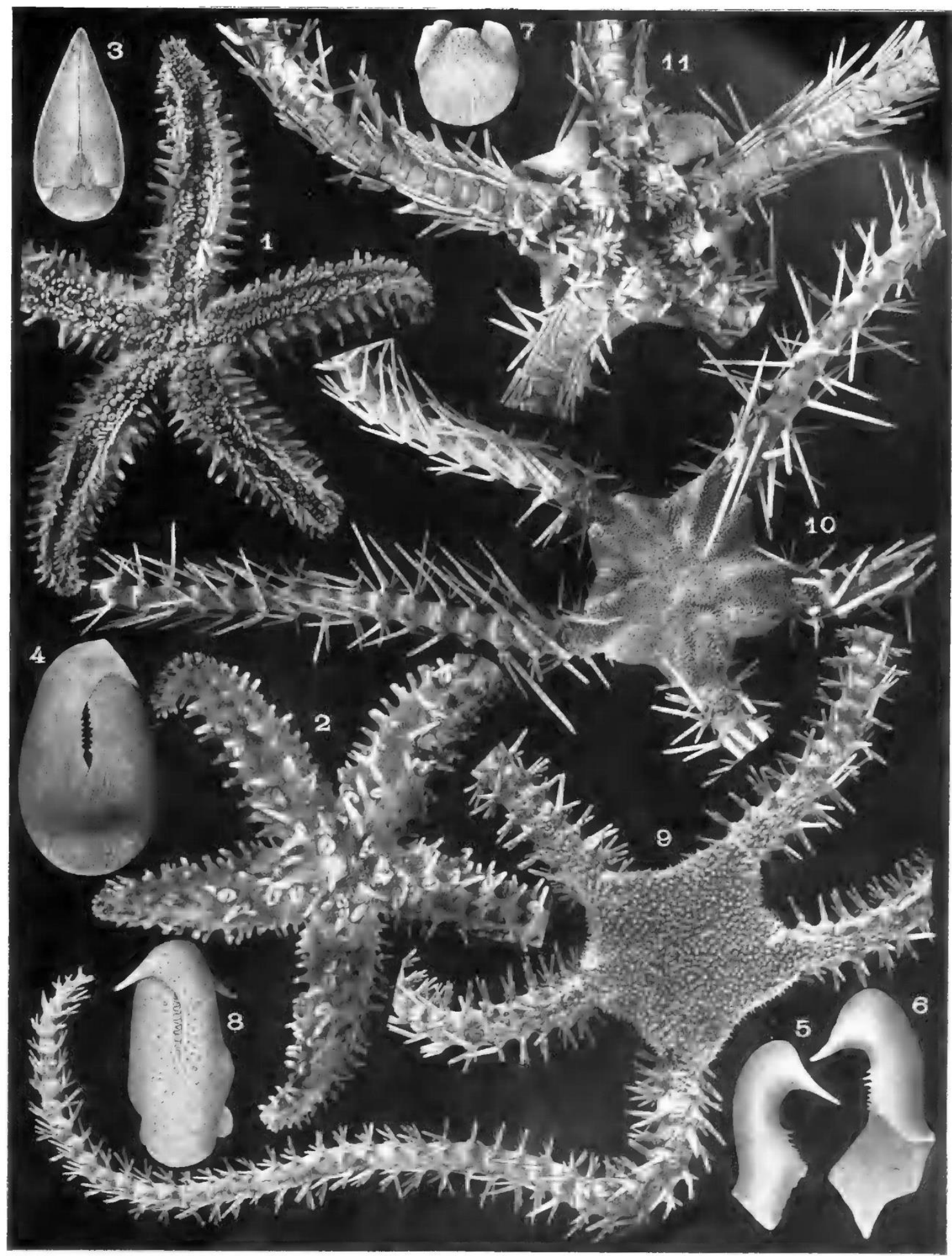

R. Kiehler fecit 


\section{PLATE VII}

Fig. 1.-Pseudabatus nimrodi, Individual A. Lateral view. Magnification 1.4.

Fig. 2.-Pseudabatus nimrodi, Individual B. Lateral view. Magnification 1.4.

Fig. 3.-Pseudabatus nimrodi, Individual B. Ventral surface. Magnification 1.4.

Fig. 4.-Pseudabatus nimrodi, Individual B. Apical region. Magnification 4.

Fig. 5.-Pseudabatus nimrodi. Valve of a globiferous pedicellaria. Magnification 100.

Fig. 6.-Pseudabatus nimrodi. Valve of a didactyl pedicellaria. Magnification 65.

Fig. 7.-Pseudabatus nimrodi. Didacatyl pedicellaria. Magnification 35.

Fig. 8.- Pseudabatus nimrodi. Valve of a rostrate pedicellaria. Magnification 55.

Fig. 9.-Ophioglypha resistens. Dorsal surface. Magnification 3.2.

Fig. 10.-Ophioglypha resistens. Ventral surface. Magnification 3.2.

Fig. 11.-Ophioglypha resistens, Young individual. Dorsal surface. Magnification 6.

Fig. 12.-Ophioglypha resistens. Ventral surface of the same individual. Magnification 6.

Fig. 13.-Ophiodiplax disjuncta. Specimen of the English Antarctic Expedition; ventral surface. Magnification 4.

Fig. 14.-Amphiura algida. Dorsal surface. Magnification 14.

Fig. 15.-Amphiura algida. Ventral surface. Magnification 14. 
R. KOEHIER : ECHINODERMES

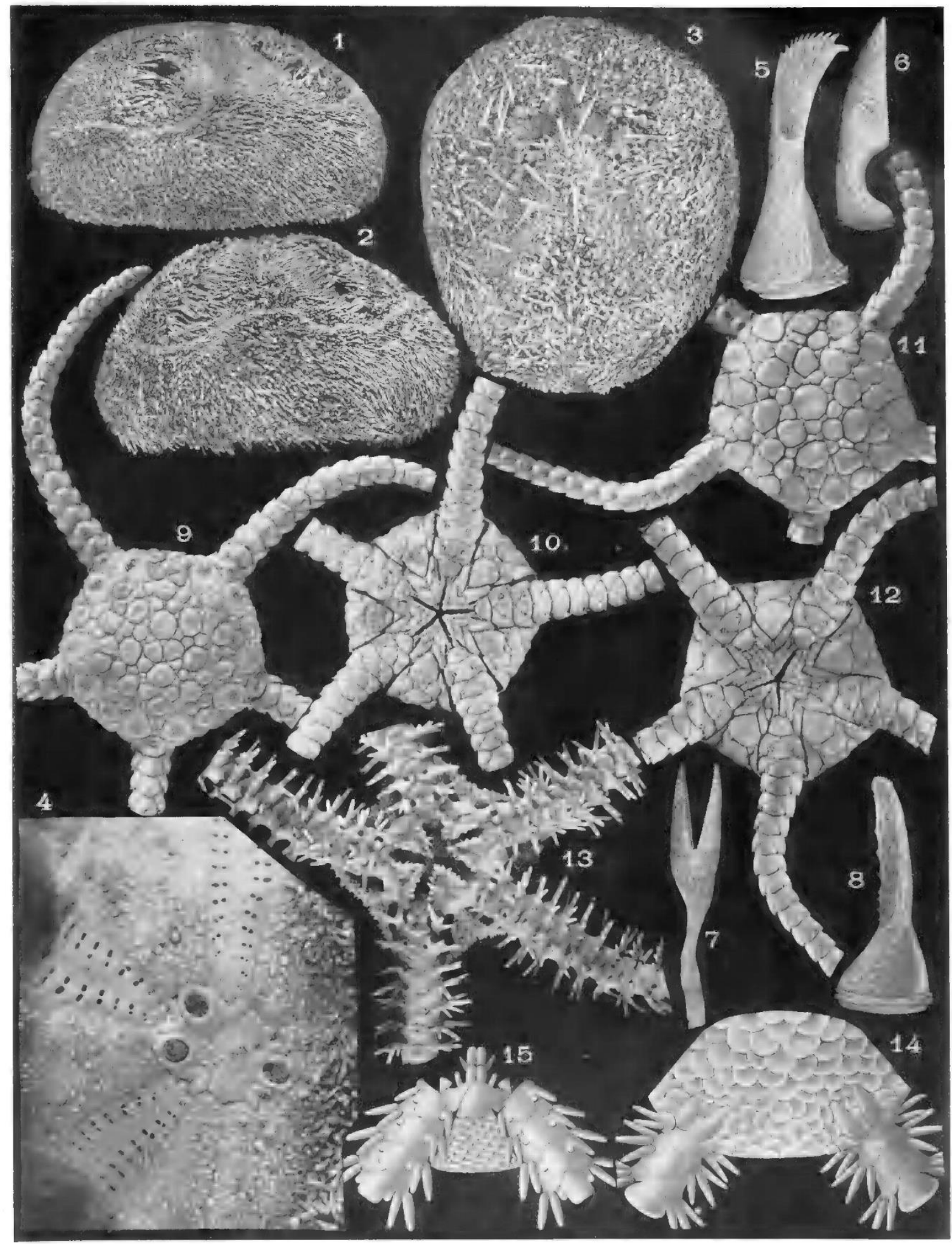

R. Koxhler fecit 


\section{PLATE VIII}

Fig. 1.-Abatus shackletoni, Female individual with its spines. Dorsal surface. Magnification 1.6.

Fig. 2.-Abatus shackletoni, Same individual seen by the ventral surface. Magnification 1.6. Fig. 3.-Abatus shackletoni, Female individual in part with spines removed. Ventral surface. Magnification 1.6

Fig. 4.-Abatus shackletoni, Same individual. Lateral view. Magnification 1.6.

Fig. 5.-Abatus shackletoni, Same individual. Dorsal view. Magnification 1.6.

Fig. 6.-Abatus shackletoni. Dorsal surface of another female individual. Magnification 1.6

Fig. 7.-Pseudabatus nimrodi, Individual B. Dorsal surface. Magnification 1.4.

Fig. 8.-Pseudabatus nimrodi, Individual A. Dorsal surface. Magnification 1.4.

Fig. 9.- Pseudabatus nimrodi, Individual B. Lateral view. Magnification 1.4.

Fig. 10.-Pseudabatus nimrodi, Individual A. Posterior surface. Magnification 1.4.

Fig. 11.-Pseudabatus nimrodi, Individual B. Posterior surface. Magnification 1.4.

Fig. 12.-Pseudabatus nimrodi, Individual A. Ventral surface. Magnification 1.4. 
R. KOEHLER: ÉCHINODERMES

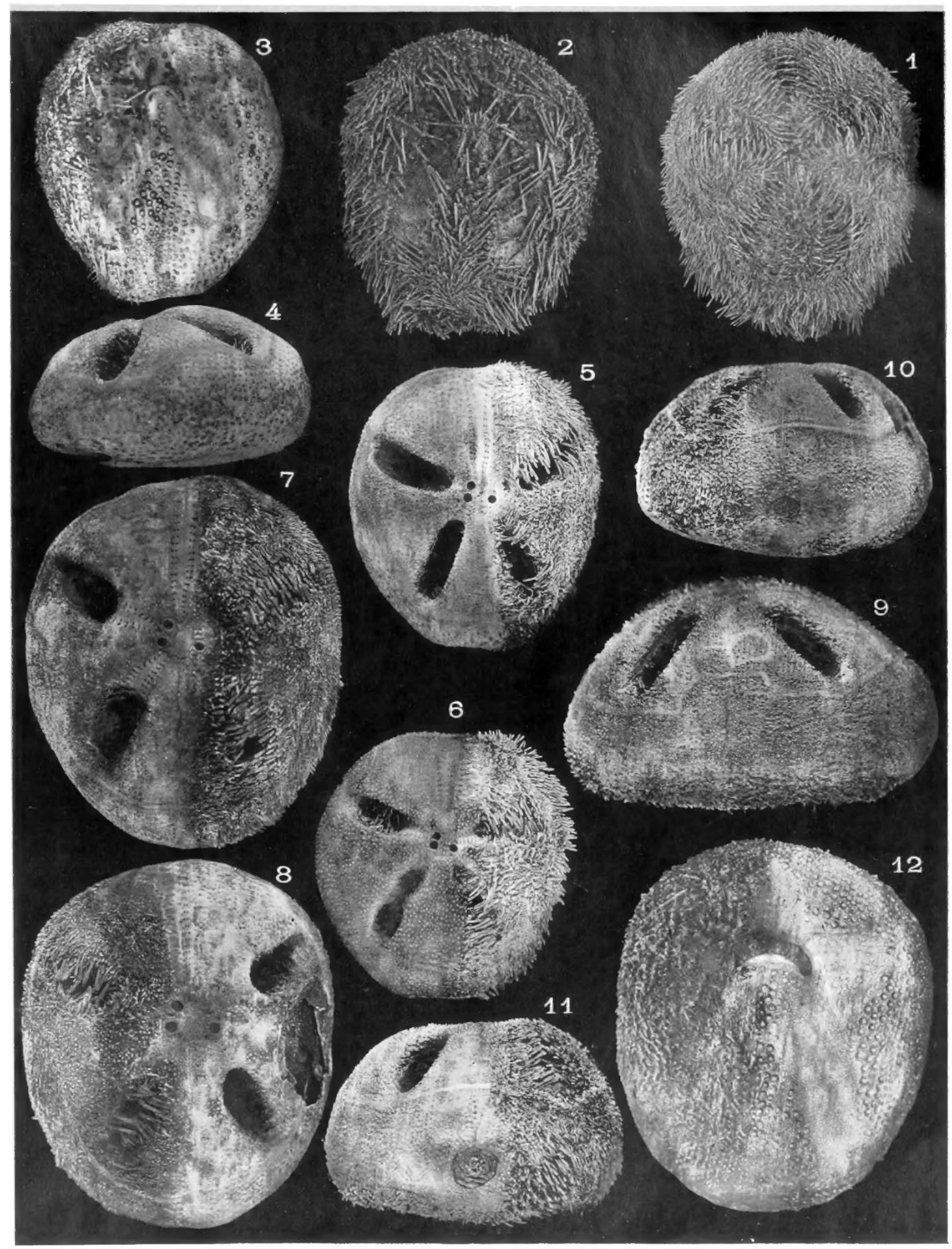

R. Koxhler fecit 